\title{
Russia's Arlington? The Federal Military Memorial Cemetery near Moscow
}

Mischa Gabowitsch

Abstract: Opened in 2013, the Federal Military Memorial Cemetery near Moscow is Russia's new national cemetery. It is to supplant the Kremlin Wall as the country's prime burial site, and was originally going to provide for the interment of both common soldiers and political as well as military leaders. Initially modeled after Arlington National Cemetery and designed as a landscaped park, the site was eventually built as a monumental complex dominated by bronze statues. This article analyzes the rival designs and the conflict surrounding the site's construction against the background of Soviet war memorials and post-Soviet commemorative practices. It also proposes a typology of national cemeteries. More than Arlington, the Federal Military Memorial Cemetery resembles heroes' cemeteries in countries influenced by the ideas of revolutionary liberation struggles and socialist realism.

The Federal Military Memorial Cemetery (FMMC) near Moscow was officially opened in a solemn ceremony on 22 June 2013. For the first time in its history, Russia now has an official national cemetery. Situated next to the village of Sgonniki in the Mytishchi district about five miles north of the Moscow Ring Road, the complex has been repeatedly hailed as "Russia's Arlington" since the earliest stages of the planning period. Indeed, in terms of its concept and design, the new memorial echoed the best-known U.S. national cemetery, as well as similar sites in other countries. In particular, it was often suggested at the discussion and planning stage that, as with the U.S. national cemeteries, Russia's should be a resting place for common soldiers, not just state and military dignitaries. 
In the event, however, the cemetery became a burial site for the select few. In this it is similar to the Kremlin Wall Necropolis (including Lenin's Mausoleum), considered the de facto national cemetery in the Soviet era. ${ }^{1}$ In addition, the FMMC is part of an extremely, and increasingly, powerful tradition of war commemoration. While that tradition is centered on the Great Patriotic War, dated to 1941-45, its larger frame of reference is Russia's entire history, viewed as a series of military exploits. I call this perspective panhistorical militarism, a term that will be elaborated below. In terms of its planning and construction, the FMMC is also reminiscent of major Soviet and post-Soviet projects of sepulchral and memorial architecture. In practice the complex serves, above all, as a departmental cemetery for the defense ministry, which had initiated its construction and is in charge of running it.

Complicated and conflict-ridden, the construction process was beset by numerous delays. The original landscape design, conceived primarily by architects, contrasted the geometric rigor of a traditional military cemetery with the peaceful atmosphere of a forest graveyard. The sculptural elements were also to embody a tension between military honors and humble mourning. Yet the end result was a monument park whose appearance was ultimately shaped by artists working in the Soviet tradition of industrially produced figurative art. The project came to adopt a consistently triumphant, state-centered aesthetic. The defense ministry played a decisive role throughout, from finding a location for the cemetery to declaring it a restricted area.

Sources on the cemetery's construction are plentiful compared to some of its Soviet predecessor projects, as the entire

The last secretary-general to be buried there was Konstantin Chernenko, in March 1985. Since 1991 the necropolis has been officially closed to any further burials. Apart from the Kremlin, the Novodevichii Monastery cemetery has pride of place in the unofficial hierarchy of the most important time-honored burial sites. Two other sites in the prestigious Western part of the capital, near the suburban residences of the political elite along the Rublevo-Uspenskoe Highway, are branches of Novodevich'e: the district cemetery of Kuntsevo, whose new part, laid out in the 1970s, is a place of interment for second-tier members of the political and military elite, and the cemetery in Troekurovo. 
process was accompanied by detailed (albeit contradictory) media reports, and relevant documents such as court verdicts are easily accessible. Thus the FMMC makes for a perfect case study that sheds light on the logic of funerary architecture and state commemoration in the Soviet and post-Soviet tradition.

Much of the existing literature on this topic adopts a largely phenomenological approach, postulating a monolithic state that commissions war memorials and cemeteries for ideological purposes and predetermines their appearance. In recent years, however, a number of historians have drawn on archival documents to trace the construction history of several monumental and funerary complexes in detail (the distinction between the two is often blurred in the Soviet case due to a systematic practice of reburial). ${ }^{2}$ In doing so they have drawn attention to the complex and often conflictual interaction that took place behind the scenes between state decision-makers, architects and sculptors, city planners and army officers, including ideological pressure, funding problems, the significance of specific patron-client networks, and

A selection: Sabine Arnold, Stalingrad im sowjetischen Gedächtnis. Kriegserinnerung und Geschichtsbild im totalitären Staat (Bochum: Projekt, 1998), 218-303; Helga Köpstein, Die sowjetischen Ehrenmale in Berlin (Berlin: ROSSI, 2006) (highly detailed, but glossing over conflicts); Ulrike Huhn, "Auf der Rückseite des Sieges. Das sowjetische Ehrenmal in der Schönholzer Heide," in Die Schönholzer Heide. Von einer Vergnügungsstätte zum Gedenkort, ed. Museumsverbund Pankow (Berlin: Textpunktverlag, 2007), 74-92; Lisa Kirschenbaum, The Legacy of the Siege of Leningrad, 1941-1995: Myth, Memories, and Monuments (Cambridge: Cambridge University Press, 2009); Karl Qualls, From Ruins to Reconstruction: Urban Identity in Soviet Sevastopol after World War II (Ithaca, NY: Cornell University Press, 2009); Scott W. Palmer, "How Memory Was Made: The Construction of the Memorial to the Heroes of the Battle of Stalingrad,” The Russian Review 68, no. 4 (2009): 373-407; Aleksei Lastouski, Roman Khandozhko, and Iryna Sklokina, Rethinking the Soviet Memory of [sic] "Great Patriotic War" from the Local Perspective: Stalinism and the Thaw, 1943-1965 [2012]. http://www.historians.in.ua/docs/monografiyi/30rethinking-the-soviet-memory.pdf (all URLs cited in this article were accessible on 29 July 2015 unless otherwise indicated). Also very informative are: Yu. L. Kosenkova, Sovetskii gorod 1940-kh - pervoi poloviny 1950-kh godov: ot tvorcheskikh poiskov $k$ praktike stroitel'stva (Moscow: LIBROKOM, 2008) (on the urban-planning context) and T.G. Malinina, Pamiat' $i$ vremia. Iz khudozhestvennogo arkhiva Velikoi otechestvennoi voiny 1941-1945 gg. (Moscow: Galart, 2011), 186-455 (on wartime designs that remained on paper). 
aesthetic disagreements. The FMMC illustrates the complexity of these relationships particularly well. The new cemetery exposes the traditionally strained relationship between architects and sculptors as well as the usually underappreciated influence of the military apparatus on shaping commemorative culture and memorial architecture-a role that compensates for the army's strictly subordinate political status.

In this essay, I trace the planning and construction of the Federal Military Memorial Cemetery in detail and consider its significance. As background, I review the ethics, logistics, and aesthetics of gravesites and memorials for Soviet and Russian soldiers who died in the Second World War and other military conflicts, as well as-briefly-earlier discussions on national cemeteries or a national pantheon. In the final section I return to the parallels with Arlington, considering where the comparison is appropriate and where it is misleading. In doing so I develop a tentative global typology of national cemeteries. The FMMC, I argue, is most reminiscent in its underlying concept, its use and, ultimately, its aesthetics of national cemeteries in countries that gained their independence after 1945 in a liberation struggle which their political leaders subsequently used as a source of legitimacy. Finally I briefly touch upon the ongoing war in Ukraine. Placing the recently opened cemetery in a new context, that continuing conflict lends the question of how to commemorate fallen soldiers greater urgency than it has for most other European countries. ${ }^{3}$

3 I am grateful to the director of the FMMC, Vladimir Daniliuk, for an opportunity to visit the cemetery. Special thanks are due to Natal'ia Tsys', head of burial services, who gave me an extended private tour of the cemetery, explained its design and operating procedures and, moreover, provided ample information about funerary sculpture in contemporary Russia. In addition to this visit, my account is based on an analysis of written sources (press reports and published interviews, legal texts and court decisions), photos, videos, Google Earth satellite images as well as detailed interviews conducted in Moscow with Aleksandr Taranenko and Georgii Frangulian, who had created the original design for the cemetery as, respectively, the lead architect and lead sculptor (October 2015), and sculptor Aleksei Yakimenko, who had participated in the construction process (June 2015). I primarily used the online databases Integrum (press) and SudAct.ru (laws and court documents) for systematic research, and coded the sources found using MAXQDA. Financial figures are 


\section{Background, Location Search, and Burial Criteria}

As early as 1941, in the first months following Nazi Germany's invasion of the USSR, Soviet architects as well as laypeople started submitting designs for a large central victory monument or park. Some of the projects implied that it would also serve as a new national cemetery. ${ }^{4}$ Yet no such memorial was built in Moscowunlike in capitals seized by the Red Army, such as Vienna, Berlin, or Budapest, but also (mostly on a smaller scale) in Tallinn, Vilnius, Kyiv or Yerevan. The standard explanation is that Stalin wanted to quash war commemoration as a potential alternative source of political legitimacy. 5 Yet administrative factors were also at play.

indicated based on the official exchange rate in place at the time of the events referenced.

Research for this article was made possible by the generous support that the Hamburg Foundation for the Promotion of Scholarship and Culture has granted me for my project on a collective biography of Soviet war memorials. The text was originally written in German and has been translated by the author. The very first draft was a paper I gave at a conference on "War Graves, War Memorials, and Memorial Shrines as a building task" that Christian Fuhrmeister and Kai Kappel organized in Berlin in February 2014. An excerpt from the German version is forthcoming in a special issue of the Journal of the International Association of Research Institutes in the History of Art (rihajournal.org) that documents that meeting and a follow-up conference in Munich in September 2014. I would like to thank Judith Dreiling, Christian Fuhrmeister, Cordula Gdaniec, Franz Hefele, Manfred Hettling, Kai Kappel, Andrea Lermer and two anonymous reviewers for JSPPS for their helpful comments on the German version. Finally I wish to thank Julie Fedor for her thoughtful and precise editing, and participants in a workshop on "Russian Politics beyond the Kremlin" at Yale University in November 2016, particularly Nancy Ries, for remarks on the English text that resulted in a small but crucial alteration. All quotes were translated directly from the Russian.

4 Malinina, Pamiat'i vremia, 203-300.

5 This explanation seems to stem from the conflation of several arguments. The first of these dates back at least to 1955: that year Georgii Zhukov, in a famous note to the Central Committee that made the case for letting the sculptor Evgenii Vuchetich erect a monument in Stalingrad and also called for a large memorial in Moscow or nearby, argued (inaccurately) that "not a single significant monument" to the heroic victory of the Soviet people had yet been erected in the Soviet Union; Pamiatnik Pobedy: istoriia sooruzheniia memorial'nogo kompleksa Pobedy na Poklonnoi gore v Moskve: sbornik dokumentov, 1943-1991 gg. (Moscow: Komitet po telekommunikatsiiam i sredstvam massovoi informatsii Pravitel'stva Moskvy, 2005), 58-59, my 
After the end of the Second World War, the Soviet Union did gradually come to adopt many elements of the culture of military commemoration that had developed in other European countries following the First World War, including monumental burial complexes, the Eternal Flame, or the cult of the Unknown Soldier. However, it never created a central agency responsible for dealing with its war dead at home and abroad and the construction and upkeep of military cemeteries, along the lines of Britain's Imperial War Graves Commission, Germany's Volksbund Kriegsgräberfürsorge, Italy's Commissariato generale per le onoranze ai Caduti di Guerra, or the American Battle Monuments Commission. For all the supposed centralism of the Soviet system, and occasional interventions from Moscow into specific projects notwithstanding, there was a great deal of regional variation in approaches to burial and commemoration. Even formally, responsibility could lie with the military administrations in the countries occupied by the Red Army, individual party or executive bodies, or army units such as local military commissariats. In practice, as was often true of the Soviet system, individual initiative proved decisive, at all levels. Marshal Kliment Voroshilov personally supervised the design and construction of the Liberty Statue on Gellert Hill in Budapest, which involved the reburial of Soviet soldiers. ${ }^{6}$ The director of a chemical plant in a newly created settlement near Tula organized the reburial of fallen soldiers from the surrounding area and had what appears

emphasis. Secondly, Stalin's fear of returning front soldiers has been used as a catch-all explanation for post-war policies. (For a recent discussion of this topic see Robert Dale, Demobilized Veterans in Late Stalinist Leningrad [London: Bloomsbury, 2015], 164.) Thirdly, a general idea that Stalin issued a blanket gag order on expressing war memories has often been voiced by liberal journalists and historians, especially with reference to Victory Day celebrations. (For a discussion see Mikhail Gabovich [Mischa Gabowitsch], "Pamiatnik i prazdnik: etnografiia Dnia Pobedy,” Neprikosnovennyi zapas 101 (2015): 93-111, 100-101.)

6 János Pótó, Az emlékeztetés helyei. Emlékmüvek és politika (Budapest: Osiris K., 2003), 126-39, 292-94 (I wish to thank Gábor Rittersporn for providing me with a detailed summary of that chapter). 
to have been the first Eternal Flame in the Soviet Union set up to honor them. ${ }^{7}$

This jumble of responsibilities was never streamlined. It seems to have been one of the reasons why the Moscow Victory Park remained largely on paper until the end of the Soviet era, even though the cornerstone was laid as early as 1958 , and the plans were repeatedly revived. Financial considerations also played a part. The great memorials were managed in the typical fashion of grand industrial projects; thousands took part in their construction, including the reburial of remains routinely performed to sanctify the ground beneath them. The erection of the Mamaev Hill memorial complex in Volgograd in particular had demonstrated how easily the costs could get out of hand. ${ }^{8}$ A multi-year campaign in the 1970 and '8os never succeeded in raising enough donations to fund Moscow's Victory Park. ${ }^{9}$

Plans to erect a Soviet pantheon, following the Parisian model, form another important strand of the FMMC's prehistory. This was most actively discussed in 1953, in the months following Stalin's death. The building, to be constructed at an unspecified location in Moscow, was to house the remains of the party, military, and other prominent figures who had until then been buried inside or just outside the Kremlin wall, including Lenin and Stalin. The mausoleum, in contrast, would be transformed into a mere tribune. Of the many designs submitted for the pantheon, most either closely followed the Paris example or revived projects for the unfinished Palace of the Soviets. ${ }^{10}$ However, the competition was quickly and quietly terminated, as other plans for large burial

7 Anna Yudkina, “Pamiatnik bez pamiati': pervyi vechnyi ogon' v SSSR,” in Pamiatnik i prazdnik: etnografiia Dnia Pobedy, ed. Mikhail Gabovich [Mischa Gabowitsch] (Moscow: Novoe literaturnoe obozrenie, forthcoming).

8 Palmer, "How Memory was Made."

9 Pamiatnik Pobedy, 180-81.

1o Arkhitektura SSSR no. 9 (1954), 23-34; Catherine Merridale, Night of Stone: Death and Memory in Twentieth-Century Russia (London: Granta, 2000), 25765. 
complexes had been before." Thus the Soviet Union never built a central military cemetery, a pantheon, or-as was considered under Khrushchev ${ }^{12}$ - a combination of both.

It was only in the post-Soviet era that the plans were revived, this time with a clear military focus. Victory Park in Moscow, finally completed after decades of debate and planning, was opened in 1995 to mark the $5 \mathrm{o}^{\text {th }}$ anniversary of the end of the Great Patriotic War. Some designs had envisaged that the park would serve as a memorial cemetery, along the lines of the Treptower Park memorial in Berlin or Mamaev Hill in Volgograd. In the event, however, the 334-acre complex on Poklonnaya Hill was built as a recreational park without burial sites, following another widespread Soviet tradition:13 as early as the first postwar years, victory parks had been built in especially hard-won cities, such as Leningrad or Tiraspol'. ${ }^{14}$ Starting in the 196os, city planners across the Soviet Union created dozens more. Victory Parks that displayed military equipment while also including fairground attractions became a standard variety of the public city park, and the link between popular recreation and the theme of the Great Patriotic War a promising argument in funding requests submitted to Moscow. ${ }^{15}$

Thus the conclusion of the grand project on Poklonnaya Hill left open the question of a national military cemetery, just as the First Chechen War gave that question renewed urgency. In addition, the new freedom of travel made many Russian citizens discover that the burial sites of Soviet soldiers in some European countries were

" For the Estonian case see the vivid account in Ants Hein, "Denkmäler der sowjetischen Ära in Estland," in Bildersturm in Osteuropa (ICOMOS - Hefte des deutschen Nationalkomitees XIII, Munich, 1994), 69-75.

12 Stepan Krivosheev, "Ne vse tam budem," Itogi, 16 April 2007.

13 One that is shared by other countries, such as the United States: Erika Doss, Memorial Mania: Public Feeling in America (Chicago/London: University of Chicago Press, 2010), 187-252.

14 On Leningrad see Kirschenbaum, Legacy of the Siege of Leningrad, 113-150.

15 Other historical eras had served that function before. Thus in 1949 the executive committee of Molotov (modern-day Perm) wrote to the council of ministers in Moscow pointing out the upcoming anniversary of the 1905 revolution in 1955 and requesting 450,0oo rubles for, among other things, a park that would be named in the revolution's honor; GAPK (State Archive of Perm Krai), f. r-176, o. 5-1, d. $623,1.107$. 
better maintained than many a military cemetery in Russia. ${ }^{16}$ There were also new kinds of financial considerations. Under the new market conditions, burial became a costly affair. Advocates of a national cemetery for meritorious military men would constantly bring up the fact that burial at any of Moscow's more prestigious cemeteries had become prohibitively expensive even for the families of retired marshals. ${ }^{17}$

In May 1997, 39 high-ranking officers signed a letter to recently re-elected President Boris Yeltsin asking him to create a national military cemetery. They were writing in the name of a veterans' organization called Russian Combat Fellowship (Rossiiskoe boevoe bratstvo) which had apparently given generous support to Yeltsin's campaign the previous year. ${ }^{18}$ A few months later, the first media report appeared about an architectural competition supposedly launched by the government to build a cemetery for "national heroes who defended the fatherland." 19 As it happened, however, much more time would pass until the project was adopted and a competition formally announced.

It was a personnel decision that turned out to have a decisive impact. As early as January 1993, President Yeltsin had signed a law "On Immortalizing Those Who Fell Defending the Fatherland." The document did acknowledge the work of the countless volunteer search groups-the poiskoviki-that had burst into public

16 Shamil' Idiatullin, “Polnaia mogilizatsiia,” Kommersant-Vlast', 14 May 2007, 2830.

17 Roman Fomishenko, "Panteon russkoi slavy" [interview with Sergei Goriaev], Rossiiskoe voennoe obozrenie 42 (2008); Viktor Miasnikov, "Memorial pod plenkoi," Nezavisimoe voennoe obozrenie, 11 March 2011.

18 "Vladimira Putina pokhoroniat v Mytishchakh," Pravda.ru, 22 April 2003. http://www.pravda.ru/politics/22-04-2003/838641-o/; Ekaterina Sveshnikova, "Rodnye Kalashnikova smogut navestit' ego mogilu tol'ko po propusku," Moskovskii komsomolets, 25 December 2013; “Den' pamiati: sem' voprosov o sviashchennom dolge,” Pravda.ru, 21 June 2014. http://www.pravda.ru/society/ fashion/models/21-06-2014/1212954-memory-o. On financial support for Yeltsin by the "Combat Fellowship" see Aleksandr Khinshtein, Yel'tsin. Kreml'. Istoriia bolezni (Moscow: OLMA Media Grupp 2006), 548, 555.

19 "Sredi rossiiskikh arkhitektorov ob"iavlen konkurs proektov po sozdaniiu kladbishcha natsional'nykh geroev - zashchitnikov Otechestva," Argumenty $i$ fakty, 13 October 1997. 
awareness during perestroika and were often sharply critical of what they saw as the state's lack of effort to unearth the dead of the Great Patriotic War. Yet it placed responsibility for their burial and the upkeep of their graves squarely with the largely impoverished municipal administrations. A central federal office at the Defense Ministry, which the law also provided for, remained largely on paper. ${ }^{20}$ Then, in November 1998, the 45-year-old General Aleksandr Kirilin, a career officer with a Candidate of Sciences degree in military history, was appointed to head the office. Kirilin turned it into an actively functioning Military Memorial Center, finally giving foreign organizations an identifiable interlocutor. ${ }^{21}$ Over the following years, Kirilin worked to resolve questions of ownership and responsibility for Russian and Soviet war graves abroad, and supervised the creation of an online database of dead or missing soldiers. ${ }^{22} \mathrm{He}$ also became the driving force behind the planned military memorial cemetery, solving administrative and technical difficulties and, ultimately, exercising a decisive influence on the cemetery's design.

Submitting an application via the Organizing Committee for Commemorative Celebrations and Veterans' Affairs (which, renamed Victory Committee, would co-ordinate the sprawling anniversary celebrations in 2005 and 2015), he secured the president's go-ahead. ${ }^{23}$ By then, following Boris Yeltsin's resignation on 31 December 1999, that post had been taken over by Vladimir

2o On the various administrative reforms see the entry http://encyclo pedia.mil.ru/encyclopedia/dictionary/details_rvsn.htm?id=4392 and the critical analysis in Vladimir Voronov, Prodat' $i$ predat'. Noveishaia istoriia rossiikoi armii (Moscow: Algoritm, 2014), section "Grachonok tabaka" (unpaginated e-book consulted).

21 [Interview with Kirilin], Ekho Moskvy, 14 January 2013, http://echo.msk.ru/programs/razbor_poleta/98788o-echo. In the course of yet another reshuffle in 2008 , the agency was transformed into a ministerial subdepartment-a bureaucratic move which, according to a report by an expert commission, caused renewed confusion in dealing with soldiers' graves: " $U$ semi nianek ditia bez glaza': Spravka o sostoianii voenno-memorial'noi raboty po uvekovecheniiu pamiati zashchitnikov Otechestva," IA Reks, 17 October 2012, http://www.iarex.ru/articles/30242.html.

22 Accessible at www.obd-memorial.ru.

23 Sveshnikova, "Rodnye Kalashnikova." 
Putin, first as acting then, in May 2000, as elected head of state. The following summer saw the end of the most active combat operations in the Second Chechen War, whose beginning Putin had overseen as prime minister.

The greatest difficulty, initially, was to find a suitable plot of land in or around Moscow. With limits on immigration and construction all but gone, market mechanisms introduced into the housing and building sector, and financial resources increasingly concentrated in the capital, Moscow was growing rapidly, and available space was being used primarily for the lucrative construction of residential high-rises. Around Moscow, large-scale gated villa complexes and kottedzh settlements were burgeoning just as rapidly after the stringent limits that had previously regulated dacha construction were scrapped in 1990. ${ }^{24}$ What made the search even more difficult was that the new cemetery would have to be built close to an existing one if hygiene regulations protecting soils and groundwater were to be met.

At the time, two existing cemeteries in the Moscow oblast' were being discussed as new "Russian Arlingtons." In September 2000, a military section was added to the Perepechinskoe Cemetery north of Sheremet'evo airport. Following a Soviet tradition, the new section was consecrated by reburying the remains of an unknown soldier who had died in Moscow oblast' during the Great Patriotic War. Army members regardless of grade were to be buried here in egalitarian fashion. Yet that right was denied to 262 unidentified soldiers killed in the Second Chechen War. The Committee of Soldiers' Mothers, which campaigned for a dignified burial, ultimately had to inter the dead at the Bogorodskoe Cemetery, located 25 miles east of the capital. ${ }^{25} \mathrm{~A}$ nearby landfill in a disused military area was proposed by the authorities as a location for the new national cemetery, a suggestion that Kirilin rejected with

24 Merve Yucel, Segregated Landscapes. Kottedzhi of Rubljovka (Moscow: Strelka Institute for Media, Architecture and Design, 2011). http://issuu.com/strel kainstitute/docs/cottages?e=3330278/9000740.

25 "V Noginske segodnia pokhoronili neizvestnykh soldat pervoi chechenskoi voiny," Segodnia, 26 September 200o; Alla Astakhova, "Neudobnye mogily," Segodnia, 7 September 2000. 
indignation. ${ }^{26} \mathrm{He}$ also spurned a 17-acre area along Moscow's eastern boundary, next to the Nikolo-Arkhangel'skoe Cemetery, because he considered it too small. ${ }^{27}$

Finally Kirilin persuaded the Defense Ministry to make some of its own land available. In order to create space for the cemetery, it cleared another disused military testing ground, near the village of Sgonniki not far from the satellite town of Mytishchi. The remaining part of the designated building plot (near a civilian cemetery of similar size, created in $1930^{28}$ ) was contributed by the local forestry administration and a state farm, based on an agreement between the governments of Moscow and Moscow oblast'. ${ }^{29}$ The latter received 35 million rubles (then just over $\mathbf{1 . 2}$ million U.S. dollars) for its 45 acres; the Mytishchi district administration in turn set the condition that construction would involve providing the surrounding villages with sanitation and water supply systems at no cost to them. $3^{30}$ When it became clear that, at just over 130 acres, the complex would exceed the limit of 100 acres for newly created cemeteries defined in the 1996 Burial Law, the Russian government added a special exception to that piece of

26 Igor' Makhovskii, "Nash rossiiskii Arlington," Moskovskii komsomolets, 6 December 2006; Tat'iana Netreba, "Kladbishche dlia prezidentov," Argumenty $i$ fakty, 14 March 2007; Miasnikov, "Memorial pod plenkoi."

27 Krivosheev, "Ne vse tam budem."

28 Among other prominent individuals, a number of military figures are buried at the Volkovo cemetery. See "Volkovskoe kladbishche," http://skorbim.com/об щероссийский_реестр_кладбищ/волковское_кладбище_мытищи.html.

The weapons range had belonged to the defense ministry's 16th Central Research Institute, based in Mytishchi, which primarily develops communication technology for the Russian armed forces; "Federal'noe gosudarstvennoe biudzhetnoe uchrezhdenie '16 Tsentral'nyi nauchnoissledovatel'skii ispytatel'nyi ordena Krasnoi Zvezdy institut imeni marshala voisk sviazi A. I. Belova' Ministerstva oborony Rossiiskoi Federatsii,” in Voiska sviazi Vooruzennykh Sil Rossiiskoi Federatsii - 2015 (Moscow: Informatsionnyi most, 2015), 71-73.

29 Viktor Litovkin, "Memorial gosudarstvennoi skorbi," Nezavisimoe voennoe obozrenie, 28 June 2013.

3o Ol'ga Safonova, "Neumestnye razdory," Krasnaia zvezda, 18 June 20o8. In general, allotting new grounds for cemeteries appears to be a lucrative business for certain municipalities around Moscow. See Svetlana Basharova, "Podmoskovnye kladbishcha zapodozrili v nezakonnoi zastroike," Izvestiia, 24 October 2012. 
legislation, even though in other cases, such as the "little Arlington" on Perepechinskoe, the law had simply been ignored. ${ }^{31}$ All these adjustments and agreements notwithstanding, ownership of the grounds would remain contested as late as nine years after the symbolic cornerstone was placed in 2000. ${ }^{32}$ Still, by July 2001 preparations had advanced enough for Putin to issue a decree officially ordering construction of a federal military memorial cemetery. ${ }^{33}$

Thus even the prehistory of the FMMC's construction belies the idea that "the Kremlin" is always the driving force behind the construction of monumental memorial complexes-a cliché rehashed by the few Western press reports about the project. ${ }^{34}$ Before construction was even decided, and a competition announced, no less than 18 different agencies had to come to an agreement for the grounds to be secured. 35 The later debate about the selection criteria for burial at the national cemetery would be no less complex. ${ }^{36}$ The main difference from similar projects in other European countries was that the negotiations largely took place behind closed doors. Regular veterans, let alone the larger public, were not involved. This was one of the reasons why hopes for an Arlington-style national cemetery for all former combatants came to naught. The government decision of February 2004, which stipulated the criteria for burial at the FMMC, mentioned only specially decorated veterans, as well as soldiers, police, firefighters, and others who had displayed exceptional valor in giving their lives for the state. Also included were holders of high office or

${ }^{31} \quad F e d e r a l ' n y i$ zakon “O pogrebenii i pokhoronnom dele" (12 January 1996, amended on 21 April 2005), article 16, section 5.

32 Viktor Litovkin, "Memorial skorbi," Nezavisimoe voennoe obozrenie, 16 October 2009; Miasnikov, "Memorial pod plenkoi."

33 Ukaz Prezidenta Rossiiskoi Federatsii “O Federal'nom voennom memorial'nom kladbishche" (no. 829, 11 July 2001).

34 Adrian Blomfield, "Vladimir Putin's Last Resting Place-with Stalin," Daily Telegraph, 22 March 2008; Mareike Aden, "Ein pompöser Friedhof für Russlands Helden," Deutschlandfunk, 15 December 2008, http://www.deutschlandfunk.de/ei n-pompoeser-friedhof-fuer-russlands-helden.795.de.html?dram:article_id=117806.

35 Miasnikov, "Memorial pod plenkoi."

36 Ibid. 
distinctions all the way up to the president, as well as any persons designated by the president, and the spouses (but not the children) of anyone already interred. ${ }^{37}$ Thus the government missed a chance to break with the hierarchical tradition that saw the creation of separate cemeteries for officers and common soldiers at the end of the Second World War. Still, the long enumerations in the list of criteria were ambiguously phrased. As a consequence, since the FMMC's opening, relatives of "regular" veterans have repeatedly contacted the cemetery's administration to ask about a burial for their dead, only to meet with refusal..$^{8}$

Concerning the choice of location, however, the FMMC does - involuntarily yet quite radically-break with Soviet and postSoviet tradition. Visibility, site-specificity, and scenic dominance had previously been important considerations in designing and building representative burial sites for soldiers or dignitaries. In this case, the location was due primarily to economic and administrative factors. Not only did the new cemetery lack any historic significance; it was also located in the immediate vicinity of one of the largest gasfired power plants in the Moscow area. With its "fuming giant chimneys, the Sgonniki Thermal Power Plant, whose high-voltage transmission lines run directly above the cemetery," 39 comes into view before one even approaches the cemetery's gates, and looms above visitors as they walk down the "Avenue of Glory" and cross the "Bridge of Memory" into the main section of the cemetery. With its 820-foot red-and-white smokestack, the plant provides a singularly inappropriate backdrop to the monumental memorial complex (see Figure 1 below). Aleksandr Taranenko, one of the authors of the original design, believes that the plant and the transmission lines are quickly blanked out, like a theatrical rigging

37 Postanovlenie Pravitel'stva RF “O Federal'nom voennom memorial'nom kladbishche” (no. 105, 25 February 2004). By contrast, at Arlington any member of the armed forces who has seen even a single day of action is entitled at least to inurnment. Moreover, not only spouses but also minor or dependent adult children are eligible for burial there. See "Establishing Eligibility," http://www.arli ngtoncemetery.mil/Funerals/Scheduling-a-Funeral/Establishing-Eligibility.

38 Conversation with Natal'ia Tsys' at the FMMC, 28 October 2015.

39 Litovkin, "Memorial skorbi"; Litovkin, "Memorial gosudarstvennoi skorbi." 
system. $4^{40}$ Yet so far burials have only taken place north of the cemetery's central axis, a fact that a staff member explained with reference to the visual dominance of the chimneys on the southern side. $^{41}$

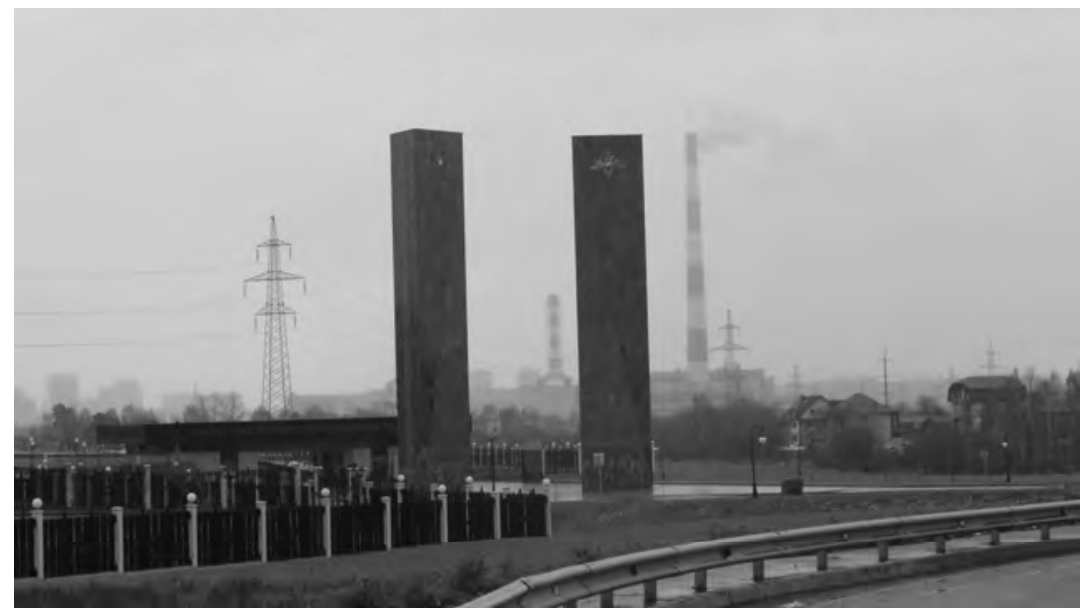

Figure 1. Stelae and gatehouse. Sgonniki Thermal Power Plant in the background. (c) Mischa Gabowitsch.

(This configuration is especially surprising if one considers that the power plant was being built just as the new cemetery was in its planning stage. It was to make way for the plant that the inhabitants of the village of Volkovo, which had lent its name to the old civilian cemetery, had been resettled since 1984. The village was torn down in 1989, and the plant's first two block-units were put into operation in 1996 and 1996. Two more were added in 2007 and 2008, during the construction of the cemetery. ${ }^{42}$ According to one of the sculptors involved in the construction, the reasons for this proximity are distinctly banal: during the planning stage, none of the

40 Interview with Aleksandr Taranenko, Moscow, 23 October 2015.

${ }^{41}$ On-site conversation with an employee of the Military Memorial Company (Voenno-memorial'naia kompaniia), which the defense ministry has put in charge of numerous aspects of managing the cemetery. 28 October 2015.

42 For technical data on the power plant see "TEC-27," http://www.mosenergo.ru/ about/present/branch/hpp-27/. 
architects involved had visited the location, otherwise it would have been easy to move the cemetery's main entrance to its eastern end, away from the highway, placing the power plant to the rear of incoming visitors. ${ }^{43}$ By contrast, one of those architects states that the cemetery's orientation was a conscious decision, as a west-east axis is appropriate for sacred and commemorative structures. ${ }^{44}$ )

Be that as it may, the choice of location did follow another long-standing tradition of military commemoration-taking into account ease of access when selecting a site for a memorial complex. Such considerations had been important factors in turning Arlington or the Mont-Valérien outside Paris into their countries' most prestigious military burial grounds, and a similar logic was often at work in the Soviet Union. Thus Khatyn', north of Minsk, was apparently chosen among hundreds of villages burned down in Belorussia by the Nazis and their allies because it was the easiest to reach from the capital. 45 The Khatyn' memorial was opened in 1969, as was the Partisans' Field near Briansk as a new central memorial to the Soviet partisans, whose location also seems to have been decided by its proximity to a provincial capital. The same goes for memorials in Volgograd and elsewhere. ${ }^{46}$ The new cemetery near Sgonniki is easy to reach from Moscow by bus or shared taxi.

43 Interview with Aleksei Yakimenko, Moscow, 6 June 2015. However, inverting the design would have made vehicle access to the cemetery more difficult and might have required road building or expansion.

44 Interview with Aleksandr Taranenko, Moscow, 23 October 2015. By contrast, when the Veterans' Organization of Moscow's Eastern Administrative District issued a complaint against the construction of one of Europe's largest shopping malls, the scandalized authors were wide off the mark: situated 1.25 miles from Sgonniki, the new complex is not visible from the cemetery, nor is it being built on "Russian soil where bloody battles were fought" ("Stroitel'stvo magazina IKEA v Mytishchakh ne zatronet voennoe kladbishche," RIA-Novosti, 21 May 2015, http://ria.ru/economy/20150521/1065817824.html), since the front line during the Battle of Moscow in 1941-42 was situated well to the west of Sgonniki and Mytishchi.

45 By contrast I am not aware of any evidence to support the oft-repeated conjecture that the site was chosen to confuse Western observers because its name sounds similar to Katyn', site of the infamous massacre of Polish officers.

46 “Memorial'nyi kompleks 'Soldatskoe pole,"' http://welcomevolgograd.com/ articles/ch/soldier_field.html. 
Moreover, the nearby village of Chelobit'evo is projected to be reachable by Moscow metro in the foreseeable future. ${ }^{47}$

\section{Competition and Initial Design}

The presidential decree left responsibility for planning the FMMC with the defense ministry, even though it had been decided that civilian dignitaries were also to be buried there. The president and government thereby continued a tradition that gave the army a say on public commemoration as a form of compensation for its lack of political influence. At the end of the Second World War, many of the first Soviet war memorials and soldiers' cemeteries both inside the USSR and in the countries liberated/occupied by the Red Army had been initiated, commissioned, or even built by army membersat a time when civilian administrations were often wary or hostile to such projects at least on Soviet soil. In some cases, politicians publicly honored certain generals to secure their support in internal power struggles. ${ }^{48}$ Before a state-sanctioned cult of the Great Patriotic War was institutionalized under Brezhnev, the commemoration of the war and its fallen was seen primarily as a task for the military. War heroes were appointed to committees that accompanied the construction of new monuments, cemeteries, or museums, such as the Panorama of the Battle of Sevastopol', 49 or Mamaev Hill in Volgograd..$^{\circ}$ Monuments were often built inside, or next to, military facilities. ${ }^{1}$ In 1960 , at a time when the most popular army

47 The station was originally going to be opened in 2020 ("Spisok stroiashchikhsia stantsii moskovskogo metro," http://mosmetro.ru/about/prospectives, page no longer accessible as of November 2016), but the plans have now been postponed for reconsideration in 2019 ("Stroitel'stvo stantsii moskovskogo metro 'Chelobit'evo' v Mytishchakh vnov' pereneseno,” TASS, 19 March 2016, http://tass.ru/ekonomika/2755180) (accessed 7 November 2016).

48 The best-known example, of course, is Georgii Zhukov: Geoffrey Roberts, Stalin's General: The Life of Georgy Zhukov (London: Icon, 2012), 244-89.

49 See e.g. Russian State Archive of Socio-Political History (RGASPI), f. 74, o. 1, d. 303.

50 Palmer, "How Memory was Made."

51 The monument to the Urals Volunteer Tank Corps, built in 1963, is a telling example. The first memorial to the Great Patriotic War to be built in the industrial city of Perm, located far from the former frontline, the monument 
commander, Marshal Zhukov, had fallen from political favor, a Zhukov Museum could still be opened near his native village. The military also had a massive presence at the public burials of party and state leaders, which were traditionally supervised by the commandant of the Kremlin's garrison, a post usually occupied by a military man since the revolution. ${ }^{2}$ Pressure from the army leadership could even secure a burial in the Kremlin Wall for a marshal against the wishes of the head of state. ${ }^{53}$

In December 2001, the defense ministry's construction and investment department finally announced an official design competition for the memorial cemetery, albeit making few efforts to publicize the call among the Russian, let alone the international architectural community. ${ }^{54}$ The contest may have been set up so as to forestall a win by the ubiquitous president of Russia's Academy of Art, Zurab Tsereteli. 55 As the favorite sculptor of Moscow's then mayor Yuri Luzhkov, Tsereteli had decisively shaped Moscow's new memorial architecture, in addition to his prolific output of monumental figurative works across a broad thematic range. He had designed the 465-foot bayonet-shaped Victory Monument in Victory Park, Russia's tallest monument. He also supervised the reconstruction of the Cathedral of Christ the Savior in 1997-2000, whose first version, built between 1839 and 1883, had been dedicated to Russia's victory over Napoleon in the first Patriotic War.

Indeed, in March 2002, Tsereteli's entry was placed last among the four designs submitted for the FMMC. The third place was awarded to a project by Viktor Chudnovtsev, head of the 20-

was built in front of the Officer's House rather than on a central city square as would later become the norm.

52 Although some of them were already in the secret services by the time of their appointment, such as lieutenant-general Sergei Sotnikov, who was in charge of the Kremlin for two decades starting in 1967.

53 Evgenii Zhirnov, "'Sidel-sidel, utrom prosnulsia, a on umer.' Sotsialisticheskii pogost,” Kommersant-vlast', 24 February 2003, http://www.kommersant.ru/ doc/365934.

54 "Razrabotka kontseptsii arkhitekturnogo oblika zastroiki Federal'nogo voennogo memorial'nogo kladbishcha v Mytishchinskom raione Moskovskoi oblasti," Konkursnye torgi, 10 December 2001, http://gostorgi.ru/91-122.htm.

Interview with Aleksei Yakimenko, Moscow, 6 June 2015. 
Zagrantekhstroiproekt project office at the defense ministry. A design by Yevgenii Yefremov, who had built a reputation as a conservator-restorer of ecclesiastical buildings since the 1950s, came in second.

The winner of the competition was the Moscow architectural bureau Mosproekt-4. Founded in 1968, the institute had been largely in charge of construction for the 1980 Moscow Olympics. In addition to sports complexes, the portfolio of the firm, which employs approximately 100 staff, includes office, cultural, and hospital buildings. The defense ministry was already aware of Mosproekt-4, as the bureau had just been tasked with building a rehabilitation center for war veterans and redesigning the Yekaterininskii Park in the Olimpiiskii Prospekt area in central Moscow, adjacent to the army's central cultural institutions. ${ }^{56}$ Mosproekt-4 already had a dedicated landscape architecture studio under the direction of Alexander Khomyakov (born 1957), who would continue to specialize in redesigning memorial parks. ${ }^{57}$ Since 1998, the bureau was directed by the prominent architect Aleksandr Bokov (born 1943), who would be elected president of the Union of Russian Architects in 2008.

Bokov and his collaborators ${ }^{8}$ submitted a concept statement that involved a combination between a densely forested rigid

56 "Rekonstruktsiia Yekaterininskogo parka," http://www.mniip.ru/proiectsframe/ 2/o/43/; "Sotsial'no-ozdorovitel'nyi tsentr veteranov," http://www.mniip.ru/proiects frame/2/o/27/.

57 Khomyakov had worked in Berlin for a long time in the 1990s. His portfolio already included a number of memorials: he had redesigned Moscow's Fraternal Cemetery for victims of World War I, created in 1915, as a memorial park in 2005, and Sevastopol's $35^{\text {th }}$ Coastal Battery memorial, dedicated to the city's defense in 1942, two years later. (His website khomyakov.info presents these and other projects.) Following the Russian occupation of Crimea in 2014, Khomyakov became an advisor to the Russian-appointed governor of Sevastopol and thus de facto the city's architect-in-chief; "Avtor proekta muzeia 35-i beregovoi batarei naznachen sovetnikom gubernatora Sevastopolia po voprosam arkhitektury i gradostroitel'stva," ForPost. Sevastopol'skii novostnoi portal, 3 December 2014, http://sevastopol.su/news.php?id=68785.

${ }_{58}$ In addition to Bokov and Khomyakov, this included the architects Yurii Geleta and Aleksandr Taranenko, employed by Mosproekt-4, the monumental painter Ivan Lubennikov (born 1951) and the well-known sculptors Lazar' Gadaev (1938- 
geometric grid and a park-like grave field inspired by wooded rural cemeteries. Yet three more years would pass before the design documentation was ready. The entire planning schedule was beset with countless delays. As early as April 2003, an official at the defense ministry projected that construction would start in the fall, and the cemetery would be opened in time for the anniversary Victory Day celebrations in May 2005. ${ }^{59}$ However, at the time of his statement no firm financial commitments had been made beyond the 45 million rubles (just under 1.45 million U.S. dollars) already spent on preliminary design work and a feasibility analysis.

Funding was only secured months later, following an intervention by Valentina Matvienko, who had recently swapped the post of deputy prime minister for that of Saint Petersburg governor and who had long taken a special interest in war commemoration. In February 2004 the Russian government finally complied with the presidential decree by publishing a decision which not only defined the criteria for burial but also earmarked the costs of construction in the federal budget and created a legal entity that would be able to supervise the FMMC's creation and later administer the cemetery. This entity was to report to the defense ministry. ${ }^{60}$ The ministry in turn designated its own project office, 20-Zagrantekhstroiproekt, as general contractor, ordering Mosproekt-4 to include some ideas from the second- and thirdplaced projects in its design. ${ }^{61}$

Now Mosproekt-4 could finally start working out the details of its project. To this purpose the firm hired several outside associates. Among other agreements, it entered into a partnership with the Combine for Monumental-Decorative Art so as to be able to employ and pay artists. The combine had, since Soviet times, specialized in the serial production of figurative sculptures. It was

2008) and Georgii Frangulian (born 1945). In 2015, the latter would win the competition to build a new central monument to Gulag victims in Moscow.

59 Viacheslav Polovinkin, then head of the bureaucratically titled Department for the Coordination and Control of the Organization of Burial Services; "Vladimira Putina pokhoroniat v Mytishchakh.”

6o Postanovlenie Pravitel'stva RF....

61 Interview with Aleksandr Taranenko, Moscow, 23 October 2015. 
now directed by the art historian Natal'ia Anikina (born 1947), who in turn brought in the combine's artistic director, Sergei Goriaev (born 1958). ${ }^{62}$ The couple (soon to be married) was reputed to be well-connected among Moscow artistic institutions. ${ }^{63}$

In May 2005, the date the cemetery was supposed to have been operational according to the original public announcement, Bokov and his extended team presented the details of their design (see Figures 2 and 3 below). ${ }^{6}$

62 Interview with Aleksandr Taranenko, Moscow, 23 October 2015.

63 Goriaev's father was the noted Soviet graphic artist and book illustrator Vitalii Goriaev (1910-82).

64 The following description is based on a presentation video (which can be viewed at http://realty.newsru.com/article/o8Jul2013/mvmk_mytishi); the rich illustrative material made available by Mosproekt-4 (http://www.mniip.ru/ proiectsframe/1/o/46/); and an illustrated feature in Russia's main architecture journal: "Final/Death," in Project Russia 39 (2006), 132-40. Additional images were made available by Aleksandr Taranenko. 


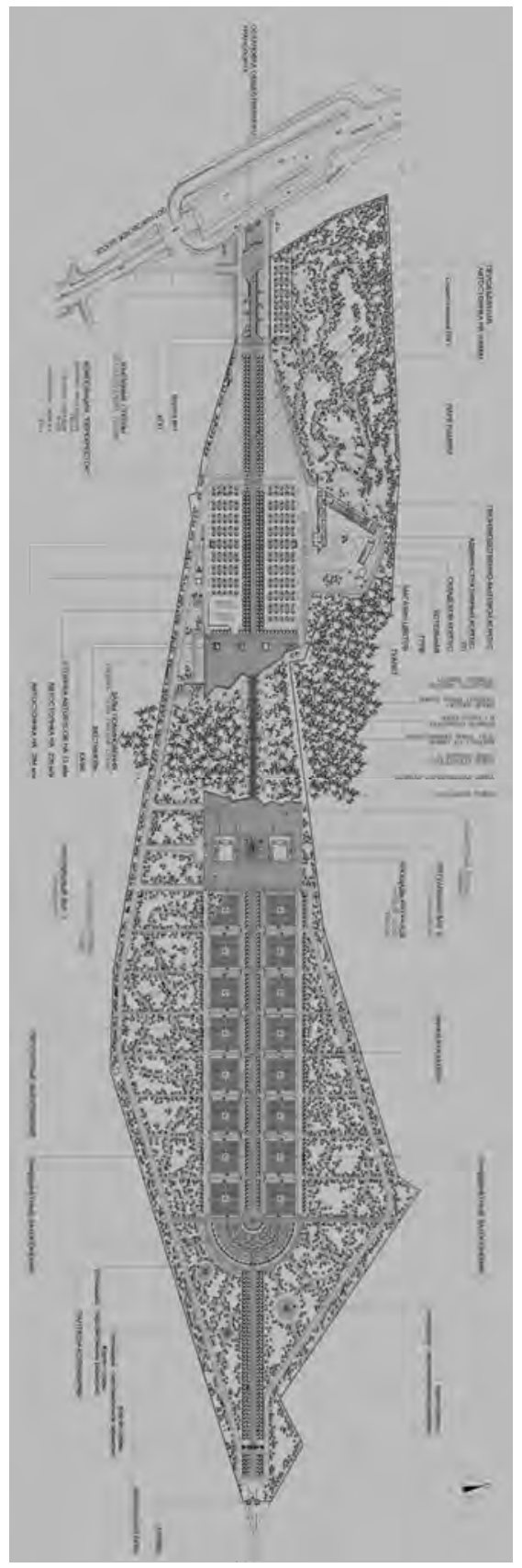

Figure 2. Original design for the cemetery: site layout. (c) copyright 2005 by Mosproekt-4. 


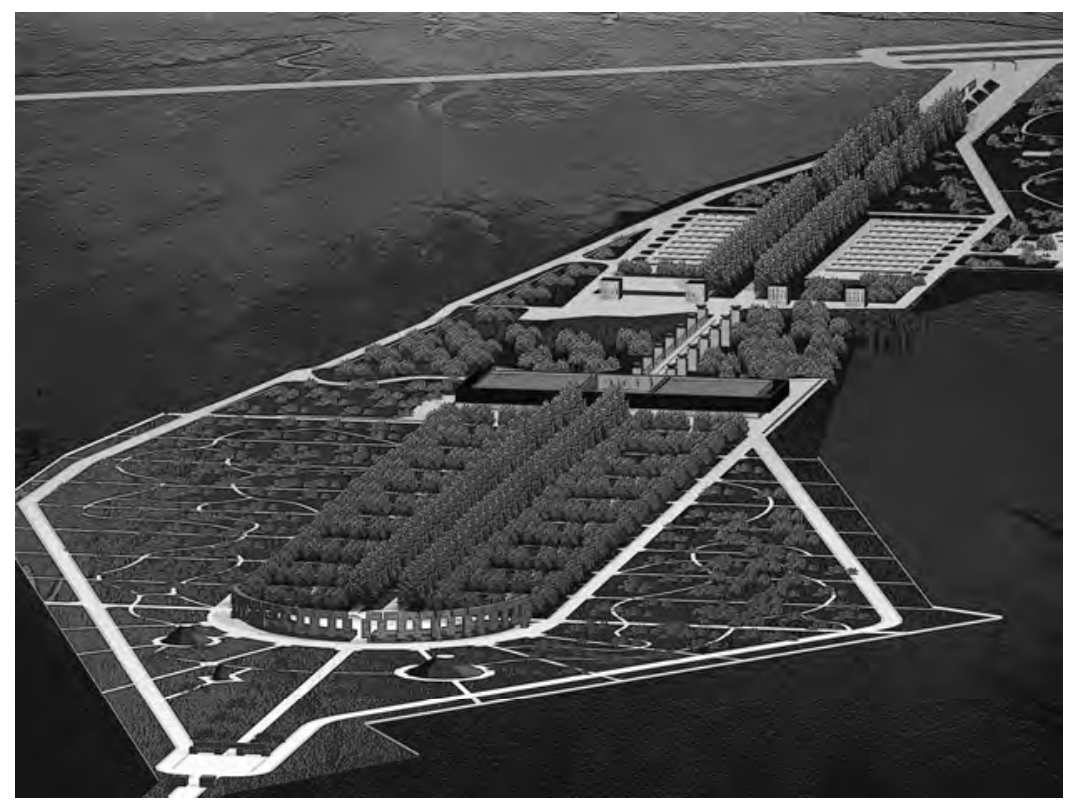

Figure 3. Original design for the cemetery: overview. (c) copyright 2005 by Mosproekt-4.

The elongated, irregular-shaped territory of the cemetery was to be bisected by a continuous horizontal central axis about 1.25 miles in length, connecting the realm of the living and the realm of the dead and equally divided between the two. The main entrance was placed just off the highway that runs past the cemetery. After entering through a broad but low gate made of polished gray granite or sandstone blocks, visitors would step onto the central cobblestone axis and walk through four pairs of red granite walls engraved with literary or pop-culture quotes about the Great Patriotic War in large letters (see Figure 4 below). The sloping rears of the walls would be covered in grass, transitioning into wooded lawns. Perched to both sides of the axis would be bronze doubleheaded eagles symbolizing the Russian state and the defense ministry-a parity championed by General Kirilin. ${ }^{80}$ To the left, in

8o Interview with Aleksandr Taranenko. Moscow, 23 October 2015. The sketches published on Mosproekt-4's website show only one heraldic animal (the state's). 
addition to one of the visitors' parking lots and a sideway leading to the maintenance area, would be a "commemorative park" with intertwined footpaths, containing no graves.

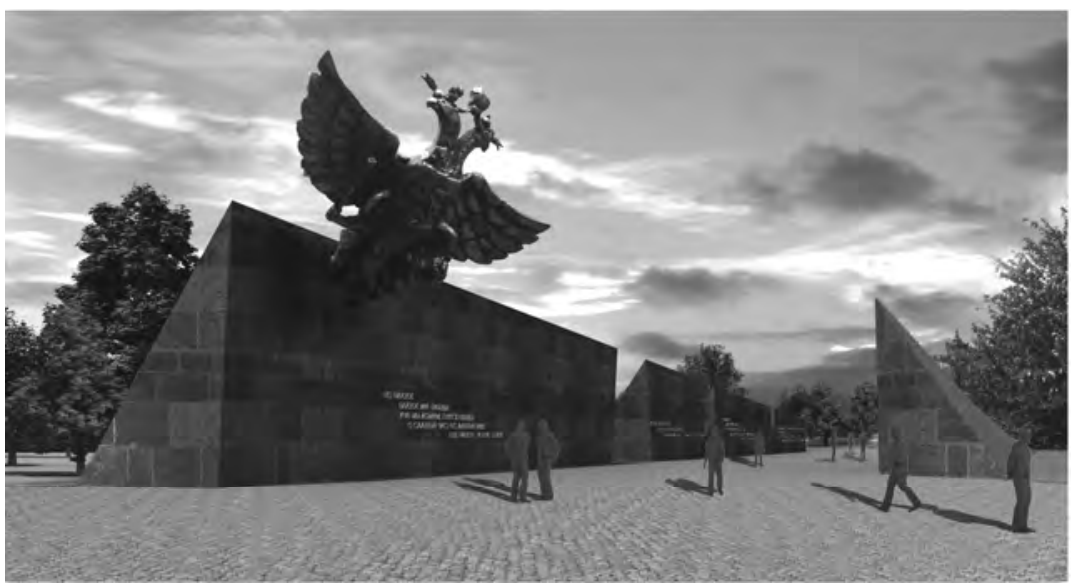

Figure 4. Original design: walls along the central axis. (c) copyright 2005 by Mosproekt-4.

Further east, the central axis would become an avenue, leading to an intersection with black cubes in each of the four corners, symbolizing the four branches of the Russian army: the aerial, ground, and marine forces, and the rear services. Continuing past another pair of parking lots for cars and buses, the avenue would reach the main entrance area. In addition to a cafeteria, a flower shop, and toilets, this would contain a memorial hall decorated with military-themed mural paintings, serving as a vestibule and side entrance for visiting groups.

Next the path leads past a natural ravine, across a "heroes' bridge" (see Figures 5 and 6 below) that would connect the world of the living with the realm of the dead, its massive supporting pillars displaying bronze reliefs symbolizing different eras of military history-from the 1242 Battle on the Ice all the way to the recent "local wars." Large firebowls would be placed on top of the pillars: instead of Eternal Flames these would project beams of light illuminating the way at night. The realm of the dead would begin 
with a glazed mortuary in dark colors: the central axis would lead right through its central courtyard, an unroofed "ritual square" with an Eternal Flame and torch-shaped light fixtures. This would be flanked by two mourning halls decorated with military flags from different eras. Sculptural groups on the themes of "mourning" and "glory" would be placed to the north-west and south-east of the building, respectively. The path would then continue through the "regular burial zone," consisting of eight square plots on each side. Divided by hedges and straight rows of trees into "quarters" for specific sub-branches (e.g. "submarine crew members"), these would be intersected by "heroes' avenues" (Figure 7). Finally, the central axis would end in front of a columbarium in the shape of a semi-circular amphitheater (Figure 8). This element was borrowed from Arlington, but whereas the amphitheater at the main U.S. national cemetery seats the bereaved during mourning ceremonies, in the Russian case the perspective was to be reversed: it would be as if the dead were scrutinizing the living who had come to bid farewell to them, symbolized by a statue of a young soldier baring and bowing his head. ${ }^{81}$ Behind the semi-circle, the central axis would resume, leading to the cemetery's rear entrance. The remaining part of the territory, surrounding the regular burial zone and the columbarium, would be a park-like landscape cemetery, containing scattered trees as well as individual features such as boulders or burial mounds.

81 Interview with Aleksandr Taranenko, 23 October 2015. 


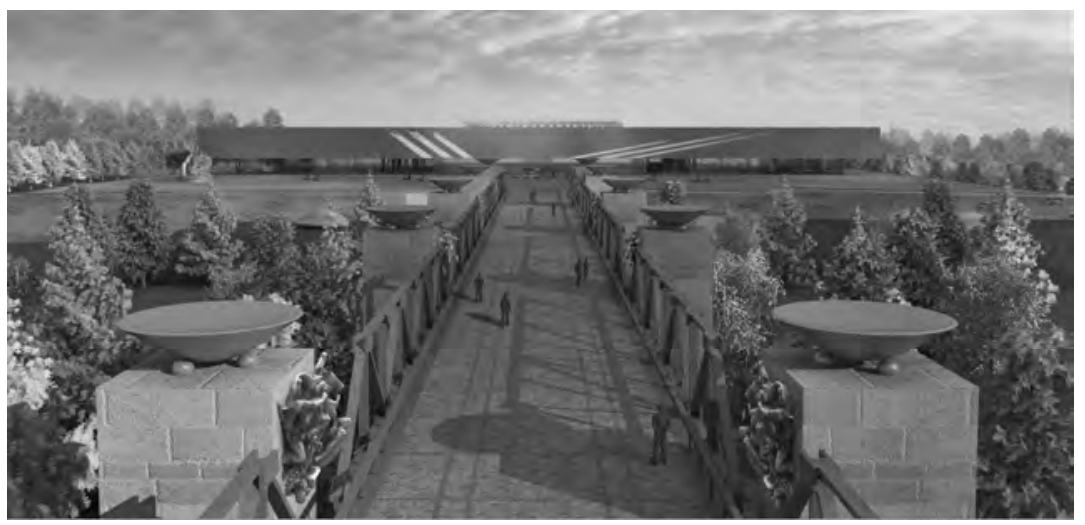

Figure 5. Original design for the Heroes' Bridge and the Mortuary. (c) Mosproekt-4.

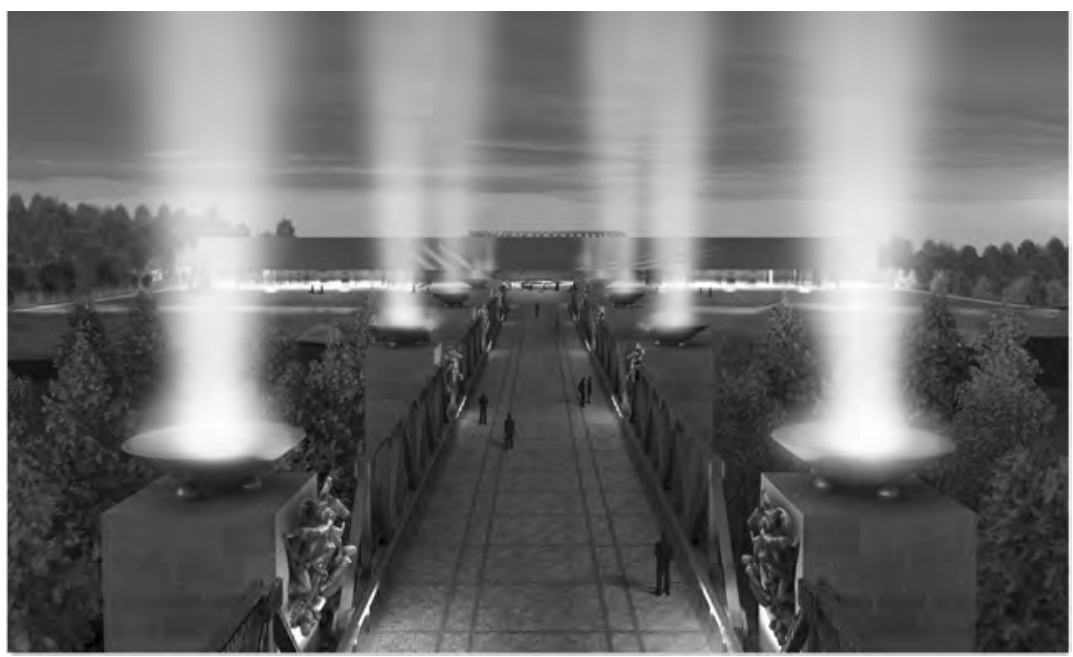

Figure 6. Original design: Heroes' Bridge at night. (C) copyright 2005 by Mosproekt-4. 


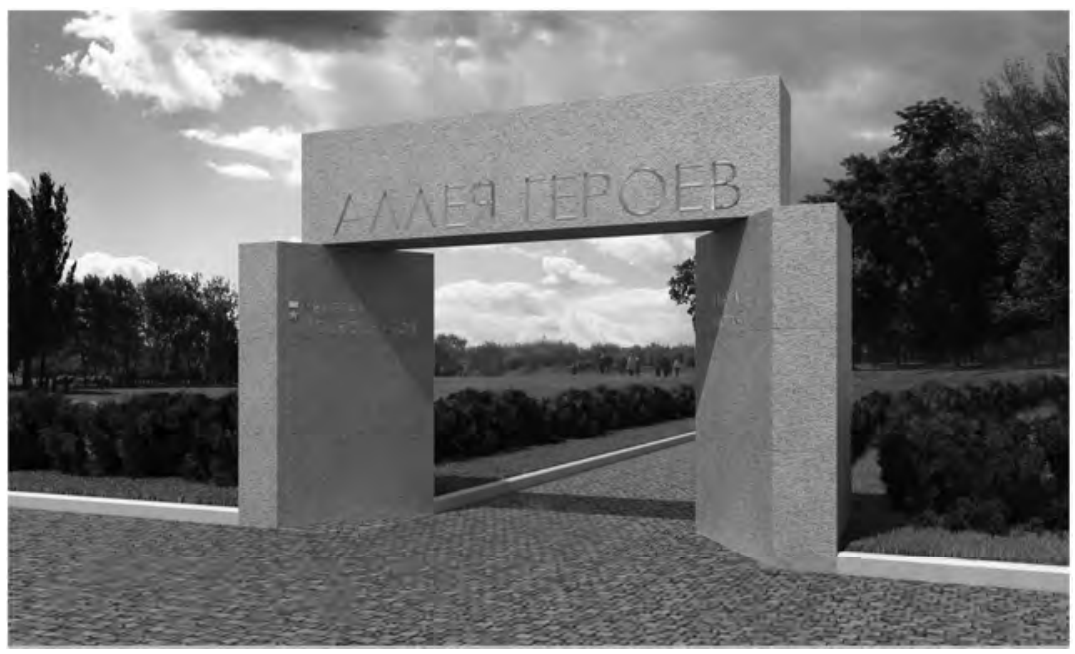

Figure 7. Original design: one of the Heroes' Avenues. (c) copyright 2005 by Mosproekt-4.

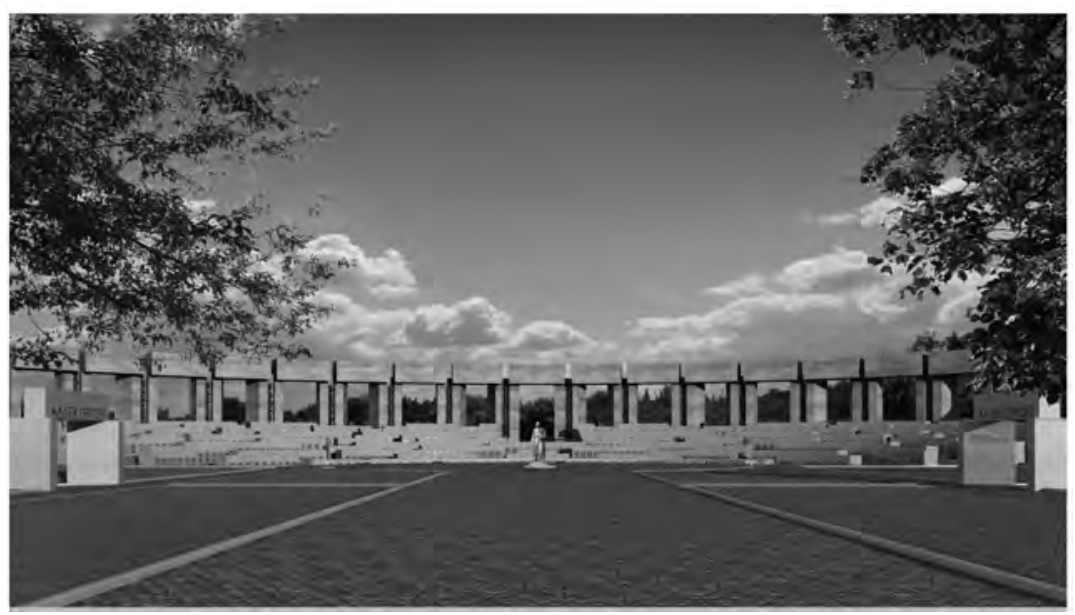

Figure 8. Original design: amphitheater-shaped columbarium and statue of grieving soldier. (c) copyright 2005 by Mosproekt-4.

By Russian standards the project was a break with the past. That a military cemetery should be designed primarily in the idiom of landscape architecture rather than sculpture was in itself novel. 
The grand Soviet complexes, from the first memorials built in 1945 e.g. in Königsberg, Vienna, and Berlin to Mamaev Hill in Volgograd, were typically so dominated by the central monuments that many observers remained unaware of their nature as burial sites, blurring the distinction between these memorials and those, like the Museum of the Great Patriotic War in Kyiv, that never included graves. In other ways as well, the design struck many commentators as "minimalistic," 82 "laconic," 83 even "ascetic" 84 or "modernist" 85 thanks above all to the low-rise structures, the relatively gentle colors, and the contrast between the rigorous geometry of the central burial zone and the bucolic, lusciously green landscaped park. "Architecture has managed to express what is most important," judged Tat'iana Malinina, the most prominent historian of Soviet memorial architecture. "However, it has left space for decorative plastic art, state symbols and insignia." 86

Yet precisely in terms of plastic art and symbolism, the design did remain rooted in the traditional culture of war commemoration that has evolved in the Soviet Union and post-Soviet Russia since the Second World War, borrowing from earlier European models. This includes the central status of the Great Patriotic War and the language of heroism and military glory, but also specific elements such as the Eternal Flame. In addition, the Heroes' Bridge and other decorative elements such as military flags testified to the design's partial embrace of an aesthetic that I call panhistorical militarism. I intend to develop this concept in greater detail in a future essay; suffice it here to point out its most important aspects:

(1) Panhistorical militarism posits an unproblematic continuity between the current state and its predecessors.

(2) This history is presented as a series of military exploits.

82 Krivosheev, "Ne vse tam budem"; Stepan Khodnev, "Razliuli mogila," Kommersant-vlast', 21 June 2010; Fomishenko, "Panteon russkoi slavy"; Safonova, "Neumestnye razdory."

83 Natal'ia Brileva, "Panteon s veslom," Trud, 20 May 2008.

84 "Vladimira Putina pokhoroniat v Mytishchakh."

85 Khodnev, "Razliuli mogila."

86 Tat'iana Malinina, "Pamiat' i vremia: novyi memorial i ego tipologicheskie osobennosti," in Project Russia 39 (2006): 134-35. 
(3) These wars are seen, for commemorative purposes, as equally important and the soldiers who fought in them as participants in a historical relay race, regardless of social, political, and ideological differences between them.

Thus panhistorical militarism is distinct from the mere exaltation of soldierly feats through the use of classical, allegorical motifs in their portrayal. It also differs from the use of memorial or gravestones to honor soldiers of subsequent wars in a location already used as a burial site, such as in Bezzecca in the Trentino, in Treuenbrietzen near Berlin, or in many Soviet or post-Soviet military cemeteriese.g. Plevna in Bulgaria or Bolesławiec (Bunzlau) in Lower Silesia, where sepulchral memorials for $19^{\text {th }}$ century Russian generals were renovated immediately after the end of the Second World War and expanded by adding communal graves for Soviet soldiers. In terms of funerary architecture, a closer approximation to panhistorical militarism would be the Military-Historical Memorial Cemetery in Bender (Transnistria), where the remains of soldiers from various wars since the $18^{\text {th }}$ century have been reburied.

The first prominent sculptural example of the aesthetic of panhistorical militarism was a bronze statue dedicated to the "defenders of the Russian land" by sculptor Anatolii Bichukov. This composition, installed in 1995 outside the new Victory Park, shows a warrior from medieval Russian epic tales standing next to a grenadier from the Napoleonic Wars and a soldier from the Great Patriotic War. The combination has been repeatedly taken up ever since.

What may at first sight appear as a simple return to a late 19th century nationalist frame actually harbors a certain emancipatory potential in the Russian case, especially with regard to military cemeteries. Thus following the Afghan and Chechen Wars, bereaved relatives and veterans had to fight for years for a dignified burial and state recognition for the fallen, and were often compelled to hide behind aesthetic forms developed for the Great Patriotic War, ${ }^{87}$ a hierarchy of "great" and "shameful" wars reminiscent of postwar U.S.

87 Nataliia Danilova, "Memorial'naia versiia Afganskoi voiny (1979-1989 gody)," in Pamiat'o voine 6o let spustia: Rossiia, Germaniia, Yevropa, ed. Mikhail Gabovich [Mischa Gabowitsch] (Moscow: Novoe literaturnoe obozrenie, 2005), 262-81. 
history. ${ }^{88}$ The equitable juxtaposition of different armed conflicts all the way up to the current "local wars" endows death in one of the more recent wars with new legitimacy. This is echoed by the principle of equality in death initially proclaimed for the FMMCanother break with Russian tradition. Whereas British, U.S., or German military cemeteries have long followed the principle that the shape and size of grave markers should not reproduce military hierarchies, the purportedly egalitarian Soviet Union hardly ever implemented that principle, usually singling out high-ranking officers and specially decorated soldiers in the design of individual and communal graves. This was supposed to change at the FMMC: in April 2003, the above-quoted defense ministry official stated that all graves would look the same: "Only for the president we might make an exception. [His grave] will have some kind of special design." 89

Even after the design documentation was prepared, the project continued to be delayed. In October 2005, deputy defense minister Vladimir Isakov announced that construction would commence in early 2006, and the cemetery would be opened in May 2008.9.$^{\circ}$ In March 2007, another announcement projected that the first burials could take place in 2009, once the soil had settled;91 only a month later, the date was postponed by another year..$^{22}$ Yet May 2010, too, passed, and the opening ceremony was set (supposedly by order of President Dmitrii Medvedev) for the $70^{\text {th }}$ anniversary of the German invasion of the Soviet Union, 22 June 2011. ${ }^{93}$ Still later, there was talk of a partial opening on that date, followed by completion in mid-December 2011.94

88 Judith Keene, "Lost to Public Commemoration: American Veterans of the 'Forgotten' Korean War," Journal of Social History (Summer 2015): 1095-113.

89 "Vladimira Putina pokhoroniat v Mytishchakh."

9o Sergei Ostanin, "V Podmoskov'e sozdaetsia federal'noe voenno-memorial'noe kladbishche, vse raboty planiruetsia zavershit' k maiu 2008 goda," Itar-TASS, 4 October 2005 .

$91 \quad$ Netreba, "Kladbishche dlia prezidentov."

92 Krivosheev, "Ne vse tam budem."

93 Khodnev, "Razliuli mogila." According to Kirilin, this date was itself postponed from Medvedev's earlier target date of 1 June: Mikhail Bykov, "Dozhit' do vechnoi pamiati," Russkii mir, 4 July 2011.

94 Miasnikov, "Memorial pod plenkoi"; Bykov, "Dozhit' do vechnoi pamiati." 
But those dates, too, went by with no result, as did yet another opening date, on 9 May 2012.95 It wasn't until 22 June 2013 that Sergei Shoiguthe fourth defense minister since the cornerstone ceremony-could solemnly open the Federal Military Memorial Cemetery at last. Even then, following the first symbolic reburial of an unknown soldier from Smolensk oblast', several more months would pass before the first regular burial—that of weapons designer Mikhail Kalashnikov—could take place. ${ }^{96}$ All in all, the FMMC was longer in the making than the technically much more complicated memorial on Mamaev Hill in Volgograd, not to mention swiftly completed projects such as the Treptower Park memorial in Berlin, opened in 1949.

\section{Conflicts over the Cemetery's Design}

One reason for the delays was a conflict surrounding Bokov's design, which led to years of public dispute and litigation between the actors involved and left the cemetery with a radically altered appearance (see Figure 9 below).

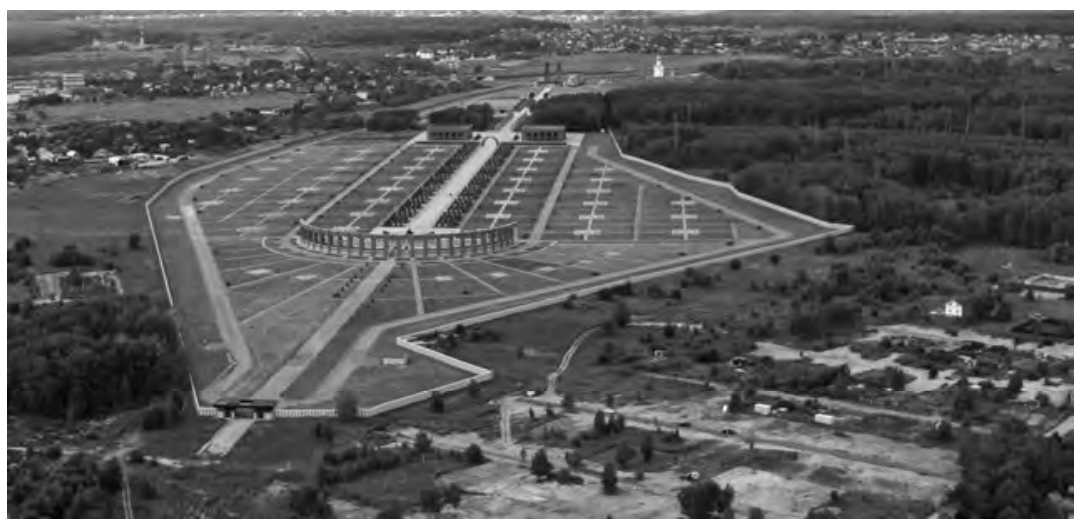

Figure 9. Aerial photo of the finished Federal Military Memorial Cemetery.

(c) copyright 2014 by Aleksei Semochkin (starbeak.livejournal.com).

95 Ol'ga Bozh'eva, "Otkrytiia federal'nogo voennogo kladbishcha zhdali 20 let," Moskovskii komsomolets, 21 June 2013.

96 Ibid. 
By the time details about the people and organizations involved in construction emerged in 2006, their configuration had changed. The commissioning entity was now the defense ministry's housing service; Chudnovtsev's 2o-Zagrantekhstroiproekt continued to act as general contractor; actual construction was going to be carried out by the Federal Agency for Special Construction, also subordinated to the defense ministry, which specializes in building military infrastructure. 97 Sergei Goriaev, of the Combine for Monumental-Decorative Art, declared himself artistic director ${ }^{98}$ or even chief architect 99 and acted as spokesman for the project alongside Kirilin and Major-General Vasilii Rudenko, the designated cemetery director. In doing so, Goriaev presented (and, until 2010, constantly adapted) a design that had changed markedly from the project submitted by Bokov and his team.

The architecture was now dominated by red and black granite-from two new vertical entrance stelae decorated with Florentine mosaics on the themes of "mourning" and "farewell" via the entrance building (now a closed gatehouse) and the pavilions in the realm of the living all the way to the amphitheater-style columbarium. Everywhere, down to details such as the interior design of the mourning hall, Bokov's comparatively airy and understated architectural style had been replaced with a massive monumentalism dominated by pictorial and sculptural elements. The (enlarged) central axis now led straight to the branches-of-thearmy intersection (Figure 10 below), dispensing with any further eye-turners. One of the most conspicuous changes concerned the bridge, now titled "Bridge of Memory" or "Heroes' Avenue" (Figure 11). Its pillars were now decorated with larger-than-life, brightly

97 More precisely, construction was carried out by ZAO Spetsstroikontrakt, a subsidiary of Spetsstroi.

98 Irina Fil'chenkova, “Arkhitekturnyi konflikt," Archi.ru, 2 February 2007, http://archi.ru/russia/3422/arhitekturnyi-konflikt.

99 Makhovskii, "Nash rossiiskii Arlington."

100 Including tall stelae had been discussed in the planning phase, but according to Aleksandr Taranenko (interview, 25 October 2015) the district's chief architect had advised against them, as, by the early 200os, the district was already planning to build new apartment towers in close vicinity to the future cemetery, which would compete with any vertical structures. 
polished bronze statues of Russian warriors from different ages, from the medieval knights to post-Soviet special units. A huge bronze Pietà was placed inside a round reflecting pool in front of the columbarium; an Eternal Flame rose up from the pool in front of the statue (Figures 12 and 13). Instead of being connected across an open courtyard, the two mortuaries were now placed in two separate buildings on either side of the central axis, which then continued below a bell suspended from an arch. The arch in turn was flanked by a miniature Kremlin wall, designed to serve as another columbarium. Most importantly, the idea of a landscape cemetery had been abandoned. The rectangles of the regular burial zone now stretched out all the way to the northern and southern boundaries of the cemetery, whose other parts were now also dominated by rigorous geometric shapes. The trees-far fewer and far betweenwere now mostly blue spruce, exactly eleven per square.

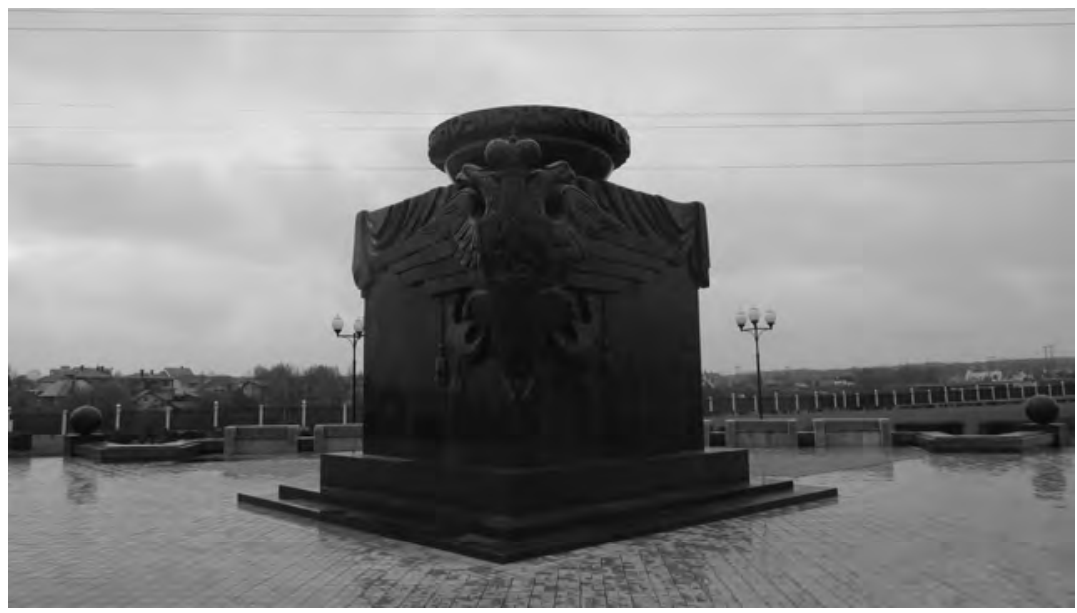

Figure 10. Federal Military Memorial Cemetery: Intersection of the branches of the army. (c) Mischa Gabowitsch. 


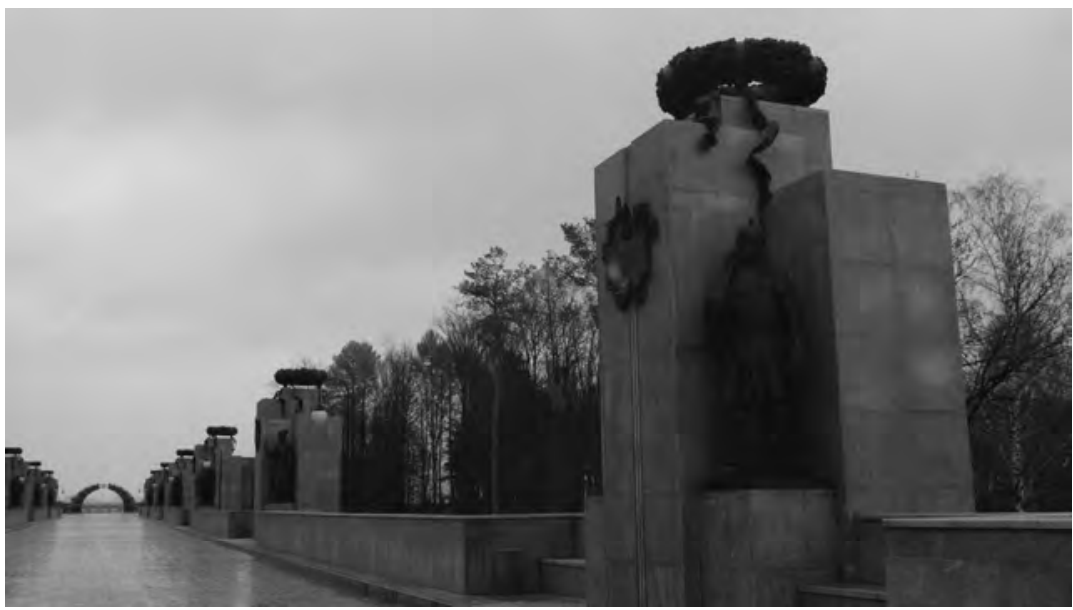

Figure 11. Federal Military Memorial Cemetery: Bridge of Memory. (C) Mischa Gabowitsch.

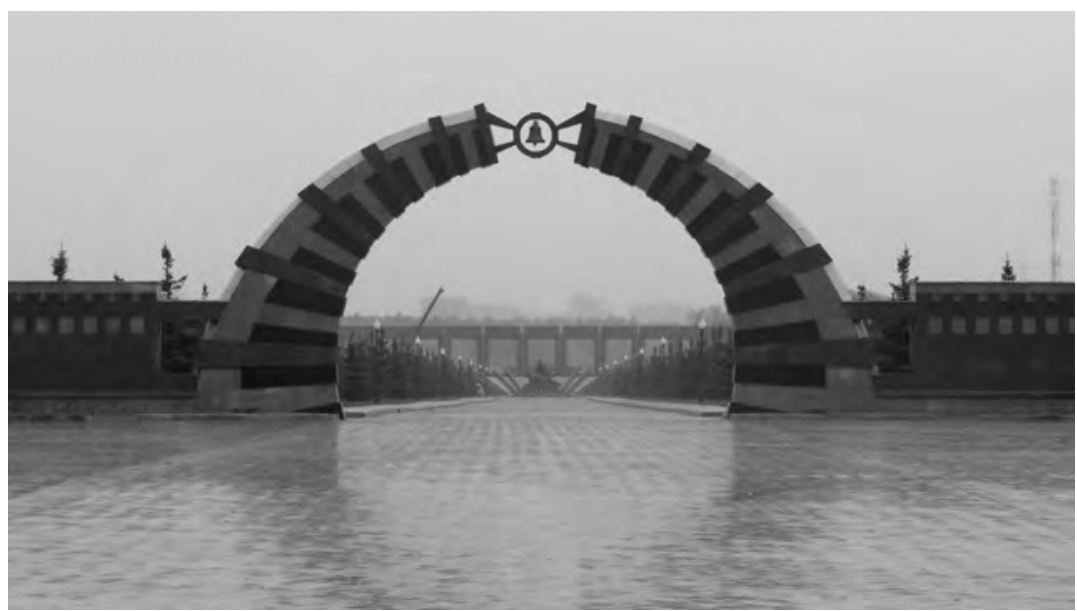

Figure 12. Federal Military Memorial Cemetery: bell arch and Kremlin wall-shaped columbarium. Behind it, the presidential avenue of the burial zone and the Pietà, Eternal Flame, and amphitheater. (c) Mischa Gabowitsch. 


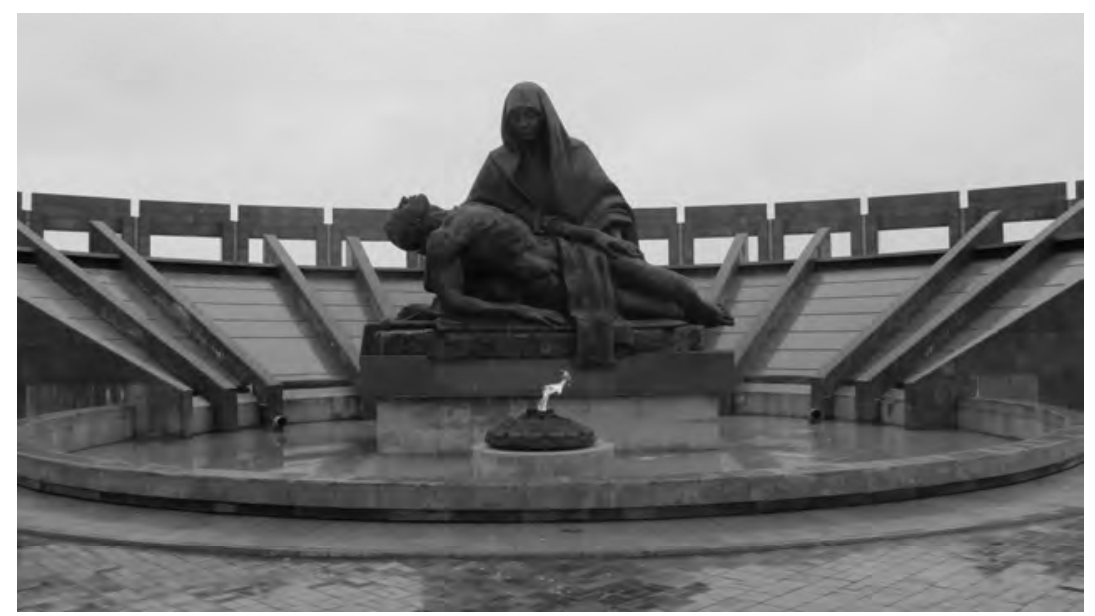

Figure 13. Federal Military Memorial Cemetery: Pietà, Eternal Flame, and amphitheater. (C) Mischa Gabowitsch.

What had happened? Unsurprisingly, there were rival explanations for the changes, and accounts of the underlying conflict.

After Bokov and his team learned that the project had been submitted to building inspection without their knowledge and without mention of Mosproekt-4, they went public, starting in February 2007 by publishing a written statement, followed by a series of press conferences. By their account, Goriaev had initially been invited to participate in the project merely to create stainedglass art, which did not even make it into the final design. He then fraudulently seized control of the project, willfully changed it and had his design endorsed by the defense ministry, even though the original version, including several volumes of technical documentation, was the one that had been approved by the relevant building control authorities. ${ }^{101}$ Then Goriaev pushed all architects,

101 Indeed (as I could ascertain in the cemetery's archive in October 2015) Goriaev had the officials in charge, all the way to the minister, sign a project that was entirely based on Mosproekt-4's designs even though it claimed authorship for his kombinat rather than Mosproekt-4. Thus all subsequent changes were 
sculptors, and painters who had participated in creating the original design out of the project. Thus at the very least he was guilty of copyright infringement. ${ }^{102}$ Mosproekt- 4 staff was barred from visiting the construction site, even though construction was still, at that stage, following their original plan. ${ }^{103}$ Goriaev owed his ascendancy to support from "a handful of generals from rear services"104 who had made sure that the original plans would not be shown to the highest officials at the ministry. ${ }^{105}$ Goriaev was also accused of using the project for personal gain. ${ }^{106}$ Now Goriaev's combine had started producing statues "whose artistic and conceptual level defies description, fitting the taste of the North Korean regime and, what is more, containing elements of plagiarism." 107 The result was a "military propaganda brochure" 108 created in a "monumentaldecorative style from totalitarian times." 109 As far as the architect's team was concerned, the worst-case scenario that Tat'iana Malinina (perhaps privy to the conflict behind the scenes) had warned of was becoming a reality: "One immediately fears that the decor might drown out the architecture. If the ubiquitous heavyweight monumental artists get their hands [on the project], that is probably exactly what will happen." ${ }^{10}$ Other critics judged Goriaev's design even more scathingly: "This is not even Stalinist monumentalism," a correspondent of the Kommersant newspaper wrote,

rather it is reminiscent of how, in the late Brezhnev era, people awkwardly tried to emulate those models from the postwar years. [...] Without doubt it

introduced only after Goriaev had positioned himself as the ministry's main interlocutor.

102 Fil'chenkova, "Arkhitekturnyi konflikt."

103 Mikhail Sergeev, "Memorial'nyi skandal,” Versiia, 19 May 2008, http://versia.ru/vok rug-stroyashhegosya-v-podmoskove-federalnogo-voennogo-memorialnogo-kladbi shha-fvmk-razgoraetsya-krupnyj-skandal.

104 Safonova, "Neumestnye razdory."

105 Fil'chenkova, "Arkhitekturnyi konflikt."

106 "Voennyi memorial, ili kladbishche idei?," Komsomol'skaia pravda, 14 May 2008; Safonova, "Neumestnye razdory."

107 Fil'chenkova, "Arkhitekturnyi konflikt."

108 Interview with Georgii Frangulian, Moscow, 9 October 2015.

109 Sergeev, "Memorial'nyi skandal."

Malinina, "Pamiat' i vremia: novyi memorial i ego tipologicheskie osobennosti." 
is sumptuous, opoulent, pompous, but it pains me that we can express national glory only through such bombast-in a style that is state-centered, eclectic, and, most importantly, lacking any personal human depth."'

From Bokov's perspective, the FMMC would become "not a cemetery, but a Disneyland."12

Goriaev did not dispute that he had changed the project at Kirilin's behest. Without specifically mentioning Mosproekt-4, he told a journalist, using the first person plural:

Based on our analysis of foreign practice, especially the Arlington complex in Washington, we were first heading in a minimalist direction. But our customers in the army administration stipulated that the memorial should at the very first sight put people on the required solemnly mournful wavelength. And we completely redesigned the project. In the end we chose a style that is more traditional for our country-the style of imperial architecture, in which the concept of solemnity dominates against a background of mourning and inward peace. ${ }^{13}$

As Goriaev pointed out, many of the new elements-in particular the red and black granite and the blue spruce-were deliberate allusions to the Kremlin wall and Lenin's Mausoleum, which the cemetery was to replace as Russia's national pantheon. ${ }^{114}$

Moreover, from Kirilin's perspective, Bokov and his team had not been contracted to build the cemetery. They had merely submitted a project, and received payment for it; all along, the general contractor had been an entity owned by the ministry. Bokov's part of the team had failed to respond appropriately to requests for improvements and had therefore been relieved of managing the project. Thus any talk of copyright infringement was specious.

The controversy resulted in a long journey through the judicial system. Starting in 2007, a string of successive court

\footnotetext{
111 Khodnev, "Razliuli mogila."

112 Sergei Fekliunin, “Na kladbishche bespokoinen'ko,” Moskovskii komsomolets, 28 May 2008.

${ }_{13}$ Krivosheev, "Ne vse tam budem."

114 Makhovskii, "Nash rossiiskii Arlington"; Netreba, "Kladbishche dlia prezidentov"; Fomishenko, "Panteon russkoi slavy."
} 
decisions alternately awarded damages to both sides, until they finally reached a settlement in August 2015, well after the cemetery was opened and several of those involved had died. ${ }^{115}$ In typical postSoviet fashion, blows below the belt accompanied the public dispute. In June 2008, an anonymous LiveJournal blog known as the informal mouthpiece of a website specializing in kompromat published a text that accused Mosproekt- 4 of corrupt practices and attempts to exert pressure on the court. The text also claimed that Mosproekt- 4 had copied its design for the federal cemetery from the Yad Vashem memorial in Jerusalem. ${ }^{116}$ In all likelihood, this bizarre accusation emanated from the defense ministry, given the references to details of the ongoing court proceedings; one observer suggested that it was designed to make the architects appear unpatriotic $^{117}$ (possible anti-Semitic connotations of the accusation remained unmentioned). On Mosproekt-4's request, the IsraeliCanadian architect Moshe Safdie, who had redesigned Yad Vashem,

115 In March 2008, a commercial (arbitrazhnyi) court ruled in favor of Mosproekt4, awarding it 5 million rubles (approx. 212,00o U.S. dollars) in damages for intellectual property infringement, but this decision was later repealed. The appellate court agreed with the defense ministry's argument that, when the results of the competition were announced, the entrants placed first, second, and third had been asked to work together; thus Mosproekt-4 and Zagrantekhstroiproekt had subsequently acted as a joint team. The parallels between the two projects were ruled to have been due to the ministry's original specifications rather than constituting intellectual property infringement (18 October 2010). This ruling in turn was revised by the court of cassation, which found Mosproekt's multi-volume project documentation to constitute sufficient proof of independent creative work, and evidence for the opponents' claim that Chudnovtsev and Goriaev had contributed to that work to be insufficient. It thus confirmed Mosproekt's authorship, albeit this time damages were set at a symbolic 10,000 rubles-less than 320 U.S. dollars (13 September 2012). In August 2015, a judge finally got the litigants to end their protracted legal battle with a settlement (10 August 2015). For reasons of space I refrain from stating the full names of the courts involved, giving only the dates of their decisions. These can be consulted in the SudAct.ru database (reference number A40-21687/2007).

116 Anastasiia Glazkova, “'Karmannoe pravosudie' pomogaet moskovskim chinovnikam borot'sia za voennoe memorial'noe kladbishche," http://solomin. livejournal.com/227798.html, 27 June 2008.

117 Khodnev, "Razliuli mogila." 
wrote a letter to deny any similarity between the two projects. ${ }^{118}$ In the meantime, Goriaev had created a 1:10 granite model of parts of his design and displayed it at exhibitions. ${ }^{119}$ In 2010 he would go on to win the grand prize at a patriotic architecture and sculpture contest in Yekaterinburg. ${ }^{120}$

Clearly, the changes to the original design were not a singlehanded effort by Goriaev. The underlying conflict was between Kirilin - the key figure behind the entire project-and Bokov's team. To be sure, there was an aesthetic dimension to this conflict: Mosproekt-4's design, daring as it was by Russian standards, did not fit the taste of the general, who had an interest in art history but was reared in late Soviet monumentalism. Quite possibly Kirilin had already been unhappy with the results of the original contest, over which he had no complete control. Added to this, however, was a dispute between the generals and Bokov's team concerning technical aspects. The central cobblestone axis was hardly suited for transporting coffins on a gun carriage or in an armored car, as stipulated for state and military funerals (granite paving was eventually used). Many of the footpaths were also too narrow for the snowplows and other utility vehicles, and in general a cemetery mostly covered with lawns would have created logistical problems for visitors and administrators alike during the long Russian winterthis, at least, was how cemetery director Dmitrii Korobtsov would later explain the rejection of Arlington-style landscape architecture. ${ }^{121}$ Whether these objections were valid is a moot point-after all, there are grassy national cemeteries in Alaska. ${ }^{122}$ In any event Bokov did

118 "Voennyi memorial, ili kladbishche idei?"; Sergei Dmitriev, "Memorial idei," Moskovskaia pravda, 16 May 2008.

119 Fomishenko, "Panteon russkoi slavy."

120 "Vserossiiskii tvorcheskii konkurs skul'pturnykh i arkhitekturnykh proizvedenii "Nashe otechestvo," Archi.ru, http://archi.ru/contests/2614/vserossiiskiitvorcheskii-konkurs-skulpturnyh-i-arhitekturnyh-proizvedenii-nasheotechestvo.

121 Sveshnikova, "Rodnye Kalashnikova."

${ }_{122}$ Although the website of the Fort Richardson cemetery does note that access to individual gravesites can be difficult after periods of heavy snowfall: http://www.cem.va.gov/cems/nchp/ftrichardson.asp. 
not seem prepared to compromise his vision to meet such requests. ${ }^{123}$

Yet the conflict surrounding the FMMC also had a larger significance. In the Soviet Union, architects rarely trumped monumental sculptors in shaping memorial complexes or burial sites. The best-known exception is the memorial in Khatyn', whose creator, the Minsk architect Leonid Levin (1936-2014) never tired of proudly repeating that he had designed the complex using almost exclusively architectural means. ${ }^{124}$ Among other competitors, his design had won out against Yevgenii Vuchetich, loathed by many of his rivals as the epitome of bombastic monumentalism. A little later, in 1975, Levin won a commission in Volgograd, the location of Vuchetich's famous The Motherland Calls statue, to create a memorial called the Soldiers' Field, whose laconic architecture he also liked to contrast with the gigantomania of the better-known work. ${ }^{125}$ Even though in the Soviet era architects and sculptors were usually working together in large teams, the sculptors in particular were often portrayed by their rivals as quintessentially unimaginative serial artists supervising the mass industrial production of standard ware, using sheer size to make up for their lack of inspiration. Bokov's team did include two prominent sculptors, Georgii Frangulian and Lazar' Gadaev, but they had proposed individual works with artistic aspirations, designed to accentuate the landscape cemetery without dominating its appearance. The victorious Goriaev, by contrast, was a classic "monumentalist."

Which aesthetic, then, was more appropriate for the cemetery? In his comparative analysis of the commemoration of fallen soldiers in Western Europe after the First World War, Jay Winter demonstrated that it was often the return to traditional forms rather than the innovative works of the artistic avant-garde

123 Interview with Aleksei Yakimenko, Moscow, 6 June 2015.

124 See, for example: Naum Tsipis, [untitled interview with Leonid Levin], Aviv 1/2 (2007): 15-18.

125 Ibid. As usual, soldiers' remains were reburied in communal graves during the construction of both the Mother Motherland statue and the Soldiers' Field, and thus both sites are military cemeteries rather than "mere" memorials. 
that allowed survivors to come to terms with their loss. ${ }^{126}$ Shortly before the FMMC was opened, Goriaev defended its aesthetic in similar terms:

Our tenacity has prevailed: we managed to make our architectural and artistic vision clear to the defense ministry, the culture ministry and simply people who did not understand the ensemble. To show that this should not be a super-modern thing. And today the veterans thanked us and said that it turned out just as they had wanted. ${ }^{127}$

Referring to the opinion of unidentified veterans (of the Great Patriotic War, as is usually implied) is a much-employed and muchderided rhetorical device that can serve to justify just about anything in Russia. Clearly, moreover, the situation of the few surviving world war veterans almost 70 years after the end of the war can hardly be compared to the grief of the bereaved immediately after 1918. However, the dead of Russia's more recent wars, e.g. in Afghanistan or Chechnia, might be better suited for comparison. In contrast to the memorials to the Great Patriotic War, which nowadays are usually funded by the state, funerary and other monuments to the fallen of the newer wars are often commissioned by relatives and surviving comrades-in-arms. Yet they, too, rarely stray very far beyond the boundaries of the figurative monumental tradition. ${ }^{128}$ Thus it may well be reasonable to assume that the style chosen for the FMMC fits not only the taste of the defense ministry officials in charge, but also those who are, potentially, directly concerned. Still, this begs the question of whether that style is also appropriate for a site which, beyond mere military commemoration, also aspires to be Russia's central national cemetery. As there was no open discussion at the planning stage, however, this question was never put to a larger public.

\footnotetext{
126 Jay Winter, Sites of Memory, Sites of Mourning: The Great War in European Cultural Memory (Cambridge: Cambridge University Press, 1998).

127 Bozh'eva, "Otkrytiia federal'nogo voennogo kladbishcha zhdali 20 let."

${ }_{128}$ Danilova, "Memorial'naia versiia Afganskoi voiny."
} 


\section{Delays}

Beside the conflict about design, there were other reasons for the length of the construction process.

Slow cash flow was often mentioned as a delaying factor. In mid-2007, over three years after Valentina Matvienko's intervention, funding was still not entirely cleared, ${ }^{129}$ so actual construction work could not start until 2008. As late as March 2010, funding backlogs were cited as a reason for the delays. ${ }^{130}$ In addition, some of the money originally earmarked for the FMMC by the defense ministry was reportedly used for other construction projects, such as military hospital. ${ }^{131}$ The finance ministry's caution was unsurprising, since the costs skyrocketed, as often happens with such grand projects. The 865 million rubles ${ }^{132}$ (about 30 million U.S. dollars) originally budgeted for the FMMC gradually grew to 1 billion, ${ }^{133}$ then $1.6,{ }^{134} 3{ }^{135}$ and finally, upon completion, $5^{136}$ or even over 5.5 billion ${ }^{137}$ (almost 168 million U.S. dollars). The spiraling costs prompted indignant reactions; ${ }^{138}$ yet no specific evidence of corruption was ever produced. According to Bokov, whose 400 million ruble quote for his own design was undoubtedly an underestimate, ${ }^{139}$ it was the many statues that led to the rise in costs. Bokov also claimed that cash only started flowing after Goriaev took over the project. Yet this may have been simply a consequence of Goriaev's good contacts to the culture ministry's commission in charge of clearing funding. ${ }^{140}$ Nor does the problem seem to have been the production method,

\footnotetext{
129 Fomishenko, "Panteon russkoi slavy."

130 "Na kladbishche dlia voennykh geroev ne khvataet deneg," Gzt.ru, 3 March 2010.

${ }_{131}$ Litovkin, "Memorial skorbi”; Litovkin, "Memorial gosudarstvennoi skorbi."

132 Safonova, "Neumestnye razdory."

133 "Vladimira Putina pokhoroniat v Mytishchakh."

134 Ostanin, "V Podmoskov'e sozdaetsia."

135 Netreba, "Kladbishche dlia prezidentov."

136 Irina Reznik, "Panteon 'epokhi Putina'," Gazeta.ru, 21 June 2013.

137 Ibid.

${ }_{138}$ Leonid Storch, “Umirat' stalo luchshe, umirat' stalo veselee," 22 June 2013, leonidstorch.livejournal.com/10938.html.

139 Dmitriev, "Memorial idei."

140 Interview with Aleksei Yakimenko, Moscow, 6 June 2015. Another account had the supporters of Bokov's team concentrated in the culture ministry: Safonova, "Neumestnye razdory."
} 
which may appear extravagant at first sight. Thus the black granite cubes for the intersection of the army branches were produced to Russian specifications by sculptors in China, then shipped to Moscow via Saint Petersburg. ${ }^{141}$ The red granite, used copiously at the cemetery, was imported from India, Egypt, and Finland. ${ }^{142}$ However, none of this is unusual given the globalized nature of production of contemporary funerary sculpture: according to a cemetery employee who had previously spent many years working in civilian funerary services, the vast majority of sepulchral monuments in Russia are now being produced in this way, since it is cheaper and guarantees higher quality than commissioning them in Russia. ${ }^{143}$ Nevertheless, this was not unproblematic. After all, it meant that Russia's national cemetery was built in an industrialized process partly outsourced to China, using imported materials, and employing Tajik migrant laborers. ${ }^{144}$ On a rhetorical level, the national cemetery was supposed to put Russia on a par with the United States and European countries. Yet the materials used to embody Russia's glory and imperial grandeur were derived from an international division of labor and, above all, links with the global South. From the point of view of the defense ministry, this undermined the patriotic aura of the site; when it later commissioned monuments for individual graves at the FMMC, the ministry insisted that they be designed by Russian artists and produced in Russia, even if this should raise costs. ${ }^{145}$

Finally, as usual with major Soviet and post-Soviet projects, a considerable number of architects, artists, engineers, and (mostly army-owned) construction firms were involved in the process. It was not always clear who was responsible for what, and even the people in charge sometimes lost track: thus in June 2008, the designated deputy cemetery director Mikhail Zhukov was unable to state the number of people working at the site. ${ }^{146}$ When Defense Minister Sergei Shoigu solemnly opened the FMMC on 22 June 2013, he was

\footnotetext{
141 Litovkin, "Memorial skorbi."

142 Ibid.

143 Conversation with Natal'ia Tsys', FMMC, 28 October 2015.

144 Safonova, "Neumestnye razdory."

145 Conversation with Natal'ia Tsys', FMMC, 28 October 2015.

146 Safonova, "Neumestnye razdory."
} 
at pains to present this fact as an advantage and unique feature of the complex: in his words, "a huge number of professionals working to the highest standard" participated in creating the cemetery. ${ }^{147}$

\section{Russia's Arlington?}

The first monument installed in public space in Russia, the equestrian statue of Peter I in Saint Petersburg, was created in 176870 by Parisian sculptors Étienne Falconet and Marie-Anne Collot. Ever since, comparison and competition with foreign models has always accompanied the construction of monuments in Russia, including funerary ones. One of the impulses for the concerted effort, in the 196os, to create new monuments (and new cemeteries) for the dead of the Great Patriotic War was a letter Georgii Zhukov wrote to the Central Committee on 14 June 1955, pointing out that such monuments had already been erected above the graves of Soviet soldiers in the People's Democracies, including China. ${ }^{148}$

The FMMC, too, was constantly compared to other cemeteries, all the way from the initial idea until after completion. Usually they served as models, but often enough the theme was one of symbolic competition between different places of burial. The Kremlin wall and the tomb of the Unknown Soldier were frequently mentioned along with other well-known Moscow cemeteries. ${ }^{149}$ Further civilian burial sites were also named as predecessors, including the Piskarevskoe, Serafimovskoe, and Literarorskie mostki (Writers' Footway) cemeteries in Saint Petersburg. ${ }^{150}$

Yet international comparison always remained the dominant theme. The framework shared by those involved in creating the cemetery and most of the journalists writing about it was the

147 "V Podmoskov'e otkryto memorial'noe voennoe kladbishche," Grani.ru, 22 June 2013.

148 Pamiatnik Pobedy, 58-59 (also see note 5 above).

149 In addition to the Kremlin wall, primarily the Novodevich'e cemetery and its branches (e.g. "Vladimira Putina pokhoroniat v Mytishchakh"), the Kuntsevskoe (Boris Yamshanov, "Filial kremlevskoi steny," Rossiiskaia gazeta, 3 March 2004) and Vagan'kovskoe cemeteries (Krivosheev, "Ne vse tam budem").

Malinina, "Pamiat' i vremia: novyi memorial i ego tipologicheskie osobennosti." 
customary rhetoric of modernization and catching up with global standards: "Everywhere in the world such structures inspire pride, they become places for popular worship and the expression of national consciousness." Military national cemeteries were said to exist "in practically every country," 151 "in all leading countries" or at least "in all those countries that endeavor to preserve their history." 152

In fact, as usual, "most leading countries" referred to the United States of America. References to Arlington were ubiquitous. Thus the construction of the FMMC "continued the process, begun during Soviet times, of adopting American symbols, which people in our country at some point decided to consider generic symbols of great power status." 153 Accordingly, the defense ministry officials in charge of construction only ever singled out Arlington among the foreign and domestic examples of cemeteries that they said they had visited. ${ }^{154}$ Russian generals in particular continued to measure themselves against the arch-rival. The project to create a countrywide system of subsidiaries was similarly justified with reference to Arlington and National Cemetery Administration. ${ }^{155}$

${ }^{151}$ "Vladimira Putina pokhoroniat v Mytishchakh."

152 Egor Savchenko, "Spor na sviatom meste. Sozdanie natsional'nogo panteona pod ugrozoi," Rossiiskaia gazeta, 11 August 2008. The authorities of Kazakhstan, which in 2014 also decided to build a national pantheon, were even more forthright in their use of catching-up rhetoric. Thus Arystanbek Mukhamediuly, the country's culture and sports minister, declared somewhat cryptically in January 2015: "There are national pantheons in France, in Austria, in Germany, in many leading countries. We have reached a level where we are obliged to build a National Pantheon, because a pantheon is the foundation for activity in the realm of human relations"; "Kazakhstan dostig takogo urovnia, kogda obiazan stroit' Natsional'nyi panteon-Mukhamediuly," Nasha gazeta Kostanaiskii regional'nyi portal, http://www.ng.kz/modules/news/article.php? storyid $=17405$, 30 January 2015 .

153 Nikolai Zubov, "Chem Amerika podelilas's Rossiei," Kommersant-vlast', 21 June 2010.

154 “Vladimira Putina pokhoroniat v Mytishchakh.” One member of Bokov's team of architects also visited the Hietaniemi cemetery in Helsinki; interview with Aleksandr Taranenko, 23 October 2015.

155 Bozh'eva, “Otkrytiia federal'nogo voennogo kladbishcha zhdali 20 let"; "Den' pamiati: sem' voprosov.” Analogous sites are now being built regionally. Thus, for example, the creation of an "historical memorial cemetery" was decided in Orel, as an extension of an existing graveyard. In addition to governors, mayors, 
Regarding both status and design, Arlington was constantly cited as an example-initially in positive, eventually in negative terms.

It wasn't until well into the construction process that those in charge remembered to mention well-known Soviet monuments, although as usual they omitted to distinguish between communal graves and non-sepulchral memorials. The FMMC was to become "a symbol of the all-national pride of the peoples of Russia, the state's ethical conscience, and its international authority," Goriaev proclaimed in August 2011. "Along the lines of Treptower Park in Berlin, Mamaev Hill in Volgograd, Poklonnaya Hill in Moscow, and the Malaya Zemlya (Small Land) memorial complex in Novorossiisk." ${ }^{156}$ The volte-face was completed shortly before the cemetery's opening, and the defense ministry let it be known that "the new pantheon has been designed entirely according to Russian [rossiiskie] traditions [...] and cannot be considered an imitation of the Arlington cemetery in the USA." 157 Defense Minister Shoigu, speaking at the height of the Donbass war, rejected any international comparison: "One needs only think of the Field of Mars [in Saint Petersburg], the Piskarevskoe cemetery, and the memorials in Volgograd and Kursk." ${ }^{158}$

Thus the discussion about the cemetery's design and the selection criteria for burial was dominated by analogies rather than questions of substance. Traditions, examples, and rivalries were more important than an open debate about the underlying principles that should express themselves in the construction and use of the FMMC.

Unsurprisingly, the search for predecessors turned up a hodge-podge of references: different prestigious burial sites were mentioned in the same breath, without regard to their history, outward appearance, or status. The FMMC had turned out, one journalist wrote following the opening ceremony, rather "like

and honorary citizens, those buried there will include generals of the army and secret services; Denis Peredel'skii, "V Orle poiavilos' kladbishche dlia merov i gubernatorov," Rossiiskaia gazeta, 25 July 2014.

156 Miasnikov, "Memorial pod plenkoi."

157 Bozh'eva, "Otkrytiia federal'nogo voennogo kladbishcha zhdali 20 let."

158 “Den' pamiati: sem' voprosov." 
Treptow Park in Berlin, Mamaev Hill in Volgograd, or Arlington cemetery in Washington." ${ }^{59}$

Yet in many respects the FMMC is different from all of these sites. Even as a military national cemetery, it is hardly in the same category as its supposed prototype. In many ways, Arlington is a typical example of Western soldiers' cemeteries from the second half of the $19^{\text {th }}$ and the first half of the $20^{\text {th }}$ century. Created immediately following a military conflict (the U.S. civil war) in order to bury a vast number of already fallen soldiers, it was a response to a pressing logistical and ethical problem. It was established in the vicinity of battlefield sites, and most of those buried there were common soldiers. ${ }^{160}$ The same goes for funerary complexes built years or even decades after the end of a conflict, from the North Italian ossari to the military cemeteries created by the German Volksbund in Eastern Europe after 1990. Likewise, cemeteries for repatriated bodies usually serve to bury the remains of all soldiers regardless of rank, be it in the United States or Japan. ${ }^{161}$

Despite assurances to the contrary made at the planning stage, the reality at the FMMC is, so far, very different. With the exception of the unknown soldier from Smolensk oblast' and one highly decorated veteran of the Great Patriotic War, all those buried there so far had been high-ranking officers or arms designers who made a career in the post-war era, in late Soviet or post-Soviet Russia. Not one of those interred at the national cemetery was born after 1950, nor is there a single casualty of the armed conflicts or numerous military accidents of recent years. Thus in practice the FMMC serves as a departmental cemetery for the defense ministry's top brass, or, bluntly put, a graveyard for generals. Even in its design, little is left of the initially proclaimed egalitarianism (see Figure 14

\footnotetext{
159 Litovkin, "Memorial gosudarstvennoi skorbi."

160 On the history of the cemetery, see Micki McElya, The Politics of Mourning: Death and Honor in Arlington National Cemetery (Cambridge, MA: Harvard University Press, 2016).

${ }_{161}$ On repatriation in the Japanese case see Tino Schölz, “Heldenseelen' und 'Fundamente des Friedens'. Gefallenengedenken und Kaiserloyalität," in Gefallenengedenken im globalen Vergleich, 301-28, 307. The observations about Italian and German cemeteries are based on my own extensive visits to military burial sites across Europe.
} 
below). The burial zones are divided into three categories, according to the rank of the deceased; to each zone corresponds a designated type of funerary monument.

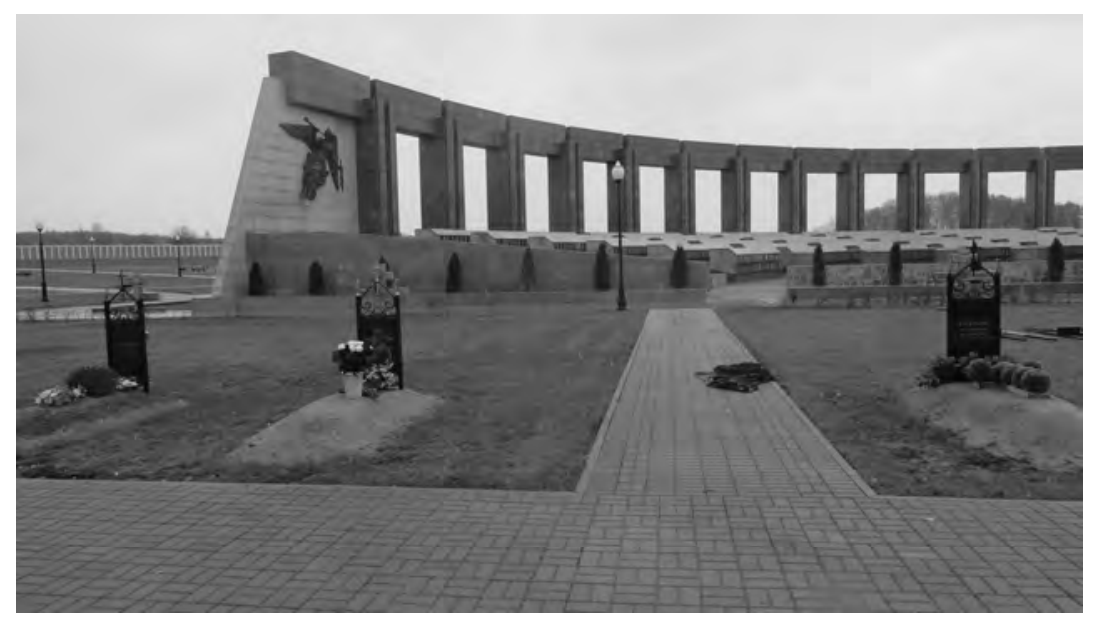

Figure 14. Graves at the Federal Military Memorial Cemetery. (C) Mischa Gabowitsch.

The FMMC's dual status-as both a military cemetery and a national pantheon-is equally striking. This type of symbolic connection between soldiers and the highest state dignitaries is by no means a uniquely Russian feature, but by European standards it certainly constitutes an exception rather than the norm. Many European cemeteries have developed over time to include separate sections for soldiers as well as graves of prominent civilian figures; yet there are hardly any military cemeteries that are systematically used to bury heads of state and government. The closest equivalent on the territory of the former Russian Empire is the hilly forest cemetery of Antakalnis in Vilnius. The result of several separate cemeteries (including military ones) merging, this site, originally created in 1809, eventually evolved into a pluri-national military cemetery. In Soviet times, the communist rulers of the Lithuanian republic were buried along the stairs leading up to a monument that honored the Red Army soldiers also interred at Antakalnis; finally, 
in the post-Soviet era, a grove of honor was added for the victims of the massacre of January 1991 as well as the presidents of independent Lithuania. Algirdas Brazauskas (1932-2010) was the first to be buried there. However, Antakalnis was not specifically created as a military-cum-national cemetery, and among those buried are numerous cultural figures and other civilians. ${ }^{162}$ In the case of the FMMC, too, a separate section was created on the president's orders for "persons in the humanities, culture, and science, as well as prominent public figures, ${ }^{163}$ but it remains empty. ${ }^{164}$ In other cases there are political tensions between military and civilian national cemeteries, as illustrated by the symbolic rivalry between the MontValérien and the Pantheon in France. ${ }^{165}$

A fusion between the two types is more common in countries whose founding is associated with an armed liberation struggle rather than with rulers whose legitimacy was religiously grounded, i.e. primarily in former colonies. ${ }^{166}$ In $19^{\text {th }}$ and $20^{\text {th }}$ century Western

162 On Antalkanis see Ekaterina Makhotina, "Archäologie der Erinnerung: Der Gedenkfriedhof und das sowjetische Ehrenmal Antakalnis in Vilnius," Jahrbuch für Historische Kommunismusforschung (2013), 247-62.

163 Rasporiazhenie Prezidenta RF №Pr-1578 o sozdanii v Moskve na territorii Federal'nogo voenno-memorial'nogo kladbishcha novogo nekropolia dlia zakhoroneniia deiatelei gumanitarnoi sfery, kul'tury i nauki, vidnykh obshchestvennykh deiatelei, RF Ministry of Culture official website, 22 June 2009, http://mkrf.ru/upload/mkrf/mkdocs2015/Отчет\%2о\%гоДепартамент\%2огос\% гоподдержки.pdf.

164 At the planning stage, Bokov and his team had, on their own initiative, designed a separate "artists' necropolis" that they proposed to build on a hill directly above the FMMC. Covering a nearly square surface area, the proposed cemetery would have featured a radial structure around a round central square and, similarly to the FMMC, a contrast between a parcellated and a forest cemetery. However, the authorities were not interested. I thank Aleksandr Taranenko for the opportunity to view the design sketches.

165 See Mechtild Gilzmer, “Frankreich: 'A nos morts.' Wandlungen im Totenkult vom 19. Jahrhundert bis heute," in Gefallenengedenken im globalen Vergleich. Nationale Tradition, politische Legitimation und Individualisierung der Erinnerung, eds. Manfred Hettling and Jörg Echternkamp (Munich: De Gruyter Oldenbourg, 2013), 175-98, 188.

166 Once again there is a possible parallel with Vilnius, where Lithuania's independence in 1990/91 is seen as liberation from Soviet occupation, and the (unarmed) defenders of the Vilnius TV tower killed in January 1991 are also buried as martyrs in Antakalnis. 
Europe, the commemoration of fallen soldiers did serve the construction of national statehood by democratizing death ${ }^{167}$ or individualizing memory; ${ }^{168}$ yet it hardly ever went as far as to put soldiers on an equal footing with heads of state. The latter continued to be buried in churches, family crypts, or on private estates. Only in states that drew their legitimacy from revolutions or liberation struggles and whose leaders let themselves be worshipped as men of the people and first-among-equals revolutionaries or soldiers did it become possible to bury heads of state with common soldiers, albeit in special graves whose architectural prominence serves as a graphic illustration of the tension between the principle of equality and the image of the chosen leader.

One example is the United States, following both the revolutionary war and the country's second founding in the civil war, which led Abraham Lincoln to create the National Cemetery system. In the U.S., presidents' claim to a burial at one of the (military) national cemeteries is based on their status as commanders-in-chief. However, only two presidents-Howard Taft and John F. Kennedy (as well as several members of his family) are buried at Arlington; in another case-that of Andrew Johnson-a national cemetery with numerous soldiers' graves grew up around a presidential tomb. ${ }^{169}$ Thus it is fair to say that Russia's Kremlin Wall Necropolis initiated a tradition of its own that remains highly influential in many countries.

Monumental national cemeteries created as burial sites for both political and military leaders of victorious national and/or revolutionary liberation struggles include the Kalibata Heroes'

167 Reinhart Koselleck, "Kriegerdenkmale als Identitätsstiftung der Überlebenden," in Identität (Poetik und Hermeneutik vol. VIII), eds. Odo Marquard and Karlheinz Stierle (Munich: Fink, 1979), 255-76.

168 Manfred Hettling, "Nationale Weichenstellungen und Individualisierung der Erinnerung. Politischer Totenkult im Vergleich,” in Gefallenengedenken im globalen Vergleich, 11-42.

169 The Oak Ridge cemetery in Springfield, Illinois, where Abraham Lincoln and his family but also other political figures and war participants are buried, is more reminiscent of European models, since it is not a national cemetery but has remained a municipal burial ground since its creation in 1865 . 
Cemetery in Jakarta (built in 1953-54); ${ }^{170}$ the Revolutionary Martyrs' Cemetery in Pyongyang (1953, later moved and twice remodeled): ${ }^{171}$ and the Heroes' Acres in Harare (1981-82) and Windhoek (2001o2) ${ }^{172}$ At the same time, the U.S. National Cemetery system was an influential model in its own right. Thus the South Korean national cemeteries in Seoul (1956) and Daeieon (1976) were built, following the U.S. model, as military burial sites reserved to fallen soldiers, expressing the principle of equality in its very design, as landscape cemeteries with standardized gravestones. However, presidents and other prominent figures are also buried at these sites, much more systematically than in the United States. The same goes for the Philippine heroes' cemetery in Taguig near Manila (1947). ${ }^{173}$

The Soviet influence is visible primarily in those countries where movements inspired by Marxism-Leninism emerged victorious from a liberation struggle, and concerns both architecture and use. The Heroes' Acre in Zimbabwe is designed, among other things, to entomb the body of the revolutionary leader and longstanding president Robert Mugabe. ${ }^{174}$ By contrast, the Martyrs' Cemetery in Pyongyang is the resting place for members of Kim Ilsung's inner circle, but not the supreme leader himself; he is buried inside the neo-classical former presidential palace, turned into the world's largest mausoleum which now also hosts the remains of his son and heir Kim Jong-il. The architecture and design vocabulary of most of these complexes is ultimately derived from Soviet-style socialist realism and the attendant standardized industrial production method. Thus the Heroes' Acres in Zimbabwe and

${ }_{170}$ Klaus H. Schreiner, Politischer Heldenkult in Indonesien (Berlin: D. Reimer, 1995), 172-74.

${ }^{171}$ Heonik Kwon and Byung-Ho Chung, North Korea: Beyond Charismatic Politics (Lanham, MD: Rowman \& Littlefield, 2012), 101-25.

${ }_{172}$ Heike Becker, "Commemorating Heroes in Windhoek and Eenhana: Memory, Culture, and Nationalism in Namibia, 1990-2000," Africa: The Journal of the International African Institute 81, no. 4 (2011): 519-43.

173 The Israeli national cemetery on Mount Herzl in Jerusalem occupies a special position, as its political and military parts are physically separated.

174 David Smith, "There must be an architect somewhere who gets very rich furnishing dictators," The Guardian, 4 August 2009, http://www.theguar dian.com/world/2009/aug/o4/letter-africa-heroes-acre-zimbabwe. 
Namibia were built by the North Korean art and construction company Mansudae Overseas Projects, as were several other military memorials and national monuments in these and other African and Asian states. ${ }^{175}$ Founded by Cho Kyu-pong, an artist who had studied in the Stalin-era Soviet Union, Mansudae espouses the principle of industrialized serial production, like the Soviet izokombinaty established in the 1920 and ' 30 . Its artists specialize in figurative portrayals of larger-than-life heroes that eschew all abstraction. As Meghan Kirkwood demonstrated for the Namibian case, this style, with its implicit reference to common features of revolutionary liberation struggles in different countries, can make a profound impression on heads of post-colonial states. ${ }^{176}$

Among the distinctive features of these complexes are the selective burial criteria. Whereas the national cemeteries in the U.S., South Korea, or the Philippines are primarily graveyards for all-or at least all fallen-soldiers, in Pyongyang or Harare allegiance to the state's founder is decisive. Thus in Zimbabwe President Mugabe regularly stresses that the Heroes' Acre is reserved to those who remained loyal to his party ZANU-PF even after the end of the guerrilla war (1964-79). This includes party cadres who never saw combat, but excludes veterans of the Revolutionary People's Army (ZIPRA) who joined the oppositional Movement for Democratic Change (MDC). ${ }^{177}$

175 In addition to the famous African Renaissance Monument in Dakar, the tallest statue in Africa, these included projects in Egypt, Syria, Angola, Botswana, Chad, DR Congo, Equatorial Guinea, Ethiopia, Mali, and Togo. See Meghan L. E. Kirkwood, "Postindependence Architecture through North Korean Modes. Namibian Commissions of the Mansudae Overseas Proiect," in A Companion to Modern African Art, eds. Gitti Salami and Monica Blackmun Visonà (Chichester, West Sussex; Malden, MA: Wiley Blackwell, 2013), 548-71, 548-49. In Laos, over 150 statues of President Kaysone Phomvihane, who died in 1992, also appear to have been produced by Mansudae; Grant Evans, "Immobile Memories: Statues in Thailand and Laos," in Cultural Crisis and Social Memory: Modernity and Identity in Thailand and Laos, eds. Shigeharu Tanabe and Charles F. Keyes (Abingdon, Oxon.; New York: Routledge, 2002), 154-84, 163. I thank Martin Großheim for pointing me to the Laotian case.

${ }_{176}$ Kirkwood, "Postindependence Architecture."

177 Werbner, "Smoke from the Barrel of a Gun," 91-92; Levi Mukarati, "National Heroes Acre losing significance?," The Financial Gazette, 8 October 2010. 
Which tradition, then, is the FMMC closest to? Its original aspirations and layout did include certain elements associated with Arlington and the U.S. National Cemetery system. Visually this is illustrated by Andrei Bokov's initial design. It is also documented in the very idea of basing the right to a state funeral on a clearly defined set of legal criteria, and in the project to create a network of such cemeteries across Russia. ${ }^{178}$ In practice, however, the complex near Sgonniki is closer to a Soviet-inspired tradition that remains influential in a range of (post-)socialist countries. In terms of construction it is the serial-style monumentalism and globalized production method that hark back to that tradition; in practical terms it is the fact that common, undecorated members of the military are excluded from burial at the cemetery. The most graphic difference from Arlington, however, is the fact that the FMMC is a restricted military area that is only accessible to close relatives of those buried or upon special request.

The ongoing war in the Donbass, where hundreds of members of the Russian armed forces have died, could have provided a (sad) occasion to apply the principle of egalitarian burial. However, this proved even less feasible than the idea of burying the unknown dead of the Chechen War at Perepechinskoe's "small Arlington" in 2000. The Russian leadership refuses to publicly acknowledge its military's involvement in the conflict; soldiers are buried in secret, ${ }^{179}$ and in May 2015 Putin declared information about instances of military members being killed or wounded during peacetime "special

Archived copy at http://web.archive.org/web/20120321073939/http://www.fin ancialgazette.co.zw/national-report/5837-national-heroes-acre-losing-signific ance.html. Manfred Hettling has made a similar point in identifying revolutionary martyr cults (as well as their religious equivalents) as a countermovement to the global tendency of equalizing the dead; Hettling, "Nationale Weichenstellungen."

${ }_{178}$ Although so far they mostly cater to political and military elites, as the abovementioned example of Orel illustrates.

179 See e.g. Aleksei Semenov, "Voina spishet vse," Pskovskaia guberniia, 26 July 2014. The paper's publisher, regional Duma member Lev Shlosberg, was brutally battered in August 2014 and later had his mandate suspended by the pro-regime majority. 
operations" a state secret. ${ }^{180}$ This is in marked contrast to Ukraine, an interesting example of the hybridization of Soviet and Western traditions of commemorating the dead of violent conflicts. ${ }^{181}$ Here, on the one hand, an open competition was held in 2014-15, with almost pedantic transparency, for a monument to the "heavenly hundred" (the civilian victims of the violence that ended Euromaidan), won by an art collective from Rimini. ${ }^{182}$ On the other hand, in June 2015 the Kyiv-based Institute for National Memory announced a competition for a standard tombstone to honor Ukrainian soldiers who died in the so-called Anti-Terrorist Operation in the Donbass-a contest closely reminiscent of a 194647 Soviet precursor, ${ }^{183}$ though with the addition of national-patriotic elements. ${ }^{184}$

The future of the FMMC is uncertain. What is clear is that this future will not be determined by its creators. Sergei Goriaev died less than three months after the opening. General Aleksandr Kirilin was retired and now works at the Central Electoral Commission. The cemetery's original director, Major-General Vasilii Rudenko, was

180 Ukaz Prezidenta Rossiiskoi Federatsii “O vnesenii izmenenii v perechen' svedenii, otnesennykh k gosudarstvennoi taine, utverzhdennyi Ukazom Prezidenta Rossiiskoi Federatsii ot 30 noiabria 1995 g. №1203” (no. 273, 28 May 2015).

181 To be sure, the Ukrainian authorities and media are often accused of underreporting the number of soldiers who have died in the Donbass (see e.g. Nataliia Dvali, "Boets Natsgvardii: Informatsiia o 363-kh pogibshikh - lozh'. V ATO ubity ne men'she 4 tysiach voennykh," Gordon, 6 August 2014, http://gordonua.com/ publications/boec-nacgvardii-informaciya-o-363-pogibshih-lozh-v-ato-ubity-n e-menshe-4-tys-voennyh-3476o.html). That, however, is not the same as classifying facts about the circumstances of an individual soldier's death as in the Russian case.

182 Numerous documents relating to the competition can be found at http://vk.com/memorialnebesnasotnya.

${ }_{183}$ Tipovye proekty pamiatnikov bratskikh $i$ individual'nykh mogil voinov sovetskoi armii, voenno-morskogo flota i partizan, pogibshikh $v$ boiakh s nemetskofashistskimi zakhvatchikami v gody Velikoi Otechestvennoi voiny (Moscow: Voennoe izdatel'stvo, 1947).

184 Thus the inscriptions must be in Ukrainian, and the designs must include a “pronounced patriotic element”; “Zaproshuiut' vziaty uchast' u konkursi proektiv typovoho nadhrobka na pokhovanniakh zahyblykh v ATO," http://www.memory.gov.ua/announce/zaproshuyut-vzyati-uchast-ukonkursi-proektiv-tipovogo-nadgrobka-na-pokhovannyakh-zagiblikh. 
replaced soon after the opening ceremony. His successor, along with most of the administration's current staff, was recruited from civilian funeral services. ${ }^{185}$ Larger tendencies will likely play a decisive role: the increasing significance of the Great Patriotic War for Russians' national self-image, the country's new military interventions beyond its borders, and the changing social and political status of the Russian army.

185 Dmitrii Korobtsov, who had previously worked as media spokesman for Moscow's state burial agency. In 2015, his deputy Vladimir Daniliuk took over as head of the FMMC. 